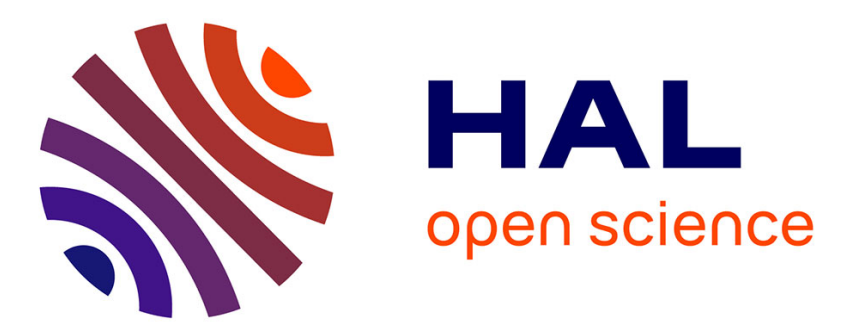

\title{
Towards understanding participatory processes: Framework, application and results
}

\author{
E. Hassenforder, A. Smajgl, J. Ward
}

\section{To cite this version:}

E. Hassenforder, A. Smajgl, J. Ward. Towards understanding participatory processes: Framework, application and results. Journal of Environmental Management, 2015, 157, pp.84-95. 10.1016/j.jenvman.2015.04.012 . hal-01579146

\section{HAL Id: hal-01579146 \\ https://hal.science/hal-01579146}

Submitted on 30 Aug 2017

HAL is a multi-disciplinary open access archive for the deposit and dissemination of scientific research documents, whether they are published or not. The documents may come from teaching and research institutions in France or abroad, or from public or private research centers.
L'archive ouverte pluridisciplinaire HAL, est destinée au dépôt et à la diffusion de documents scientifiques de niveau recherche, publiés ou non, émanant des établissements d'enseignement et de recherche français ou étrangers, des laboratoires publics ou privés. 
Author-produced version of the article published in Journal of Environmental Management, 2015, №157, p.84-95. The original publication is available at http://www.sciencedirect.com

Doi:10.1016/j.jenvman.2015.04.012

\section{TITLE PAGE}

1

\section{Article title.}

Towards understanding participatory processes: framework, application and results

Journal title.

Journal of Environmental Management

Author names and affiliations.

Emeline HASSENFORDER ${ }^{\mathrm{a}}$ (corresponding author)

${ }^{a}$ National Research Institute of Science and Technology for Environment and Agriculture (IRSTEA); AgroParisTech; The Australian National University (ANU), Fenner School of Environment and Society, 48 Linnaeus Way, Acton ACT 2601, Australia; emeline.hassenforder@anu.edu.au; Tel.: +61(0) 412585110

\section{Dr Alex Smajgl ${ }^{b}$}

${ }^{b}$ Mekong Region Futures Institute, Asoke 1655/340 Petchaburi Rd Makkasan, Radjadewi, Bangkok 10400 Thailand; alex.smajgl@mekongfutures.com; Tel. (Tha.): +66(0)9 5657 1200; Tel. (Aus.): +61 419793439

\section{Dr John Ward ${ }^{\mathrm{c}}$}

${ }^{\mathrm{c}}$ Mekong Region Futures Institute, Naga house, House 87, Unit 7, Mixay Village, Chantabouly District Vientiane Capital city, Lao PDR; john.ward@mekongfutures.com; Tel. (Lao):

+85(0)6205583 9609; Tel. (Aus.): +61(0)400674 375 


\section{processes: framework, application}

\section{and results}

\section{Abstract}

Many scholars point out that in complex and contested decision-making and planning situations, participatory processes have clear advantages over "traditional" or nonparticipatory processes. Improving our understanding of which participatory process elements or combination of elements contribute to specific outcomes demands a comparative diagnosis of multiple case studies based on a systematic framework. This paper describes the theoretical foundation and application of a diagnostic framework developed for the description and comparative analysis of participatory processes. The framework for the Comparison of Participatory Processes (COPP) is composed of three dimensions: context, process, and outputs outcomes and impacts. For each dimension, a list of variables is provided, with associated selectable options. The framework also requires clarification of three monitoring and evaluation elements. The COPP framework is then applied to five participatory processes across five different contexts: three located in the Mekong basin in Southeast Asia and two in eastern Africa. The goal is to test first if the framework facilitates the development of a comprehensive and clear description of participatory processes, and second, if a diagnostic step can be facilitated by applying the descriptions in a crosscomparative analysis. The paper concludes that despite a few challenges, the COPP 
Author-produced version of the article published in Journal of Environmental Management, 2015, N¹57, p.84-95. The original publication is available at http://www.sciencedirect.com

Doi:10.1016/j.jenvman.2015.04.012

framework is sufficiently generic to derive clear and consistent descriptions. A sample of only five case studies restricts the derivation of robust insights. Nevertheless, three testable hypothesis were derived, which would need to be tested with a much larger sample of case studies in order to substantiate the efficacy of process characteristics and attributes. Ultimately, such hypotheses and subsequent analytical efforts would contribute to the advancement of this increasingly prominent research domain.

\section{Keywords}

Participation, monitoring and evaluation, comparative analysis, outputs, outcomes, impacts

\section{Introduction}

Many scholars point out that in complex and contested decision-making and planning situations participatory processes have clear advantages over "traditional" processes. Participation may be defined as the practice of consulting and involving relevant stakeholders in the agenda-setting, decision-making, and policy-forming activities [or processes] of organizations or institutions responsible for policy development (Rowe \& Frewer, 2004). Stakeholders, according to Glicken (2000), are people or organizations either affected by the management process or who can affect it. Participation can vary depending on how many steps of the process are influenced or fully in the hands of stakeholders (Barreteau et al., 2010; Smajgl \& Ward, 2013). We refer to traditional processes as those where stakeholder participation is not explicitly designed and facilitated. Traditional or nonparticipatory processes face great challenges generating impact in situations where complex problems meet vested interests. Participatory processes have at least three advantages to establish an effective science-policy interface (Barreteau et al., 2010; Smajgl \& Ward, 2013). 
Author-produced version of the article published in Journal of Environmental Management, 2015, N¹57, p.84-95. The original publication is available at http://www.sciencedirect.com

Doi:10.1016/j.jenvman.2015.04.012

First, local contextual knowledge can be accompanied with system-focused scientific

knowledge and methodology to overcome the cognitive processing of complexity-based

challenges. Second, during the participatory process, actual decision-makers, planners, or

community members can directly experience a systems' understanding that is understood

through praxis and can therefore be readily translated into improved actions and decisions.

Third, participants are more likely to apply the new systems' understanding in the long term, beyond the temporal and planning targets of the initial participatory processes. Participation can facilitate system learning and thereby "implant" a foundational understanding, tailored to solve similar long term contested decision arenas.

Improving our understanding of which participatory process elements or combination of elements contribute to specific outcomes demands a comparative diagnosis of multiple case studies (Chess, 2000). A systematic framework that structures a consistent and coherent description of participatory processes across a diverse set of empirical situations is a necessary precursor to analytical comparisons.

This paper describes the theoretical foundation and application of a diagnostic framework developed for the description and comparative analysis of participatory processes. The framework is intended to be sufficiently generic to allow for the comparison of a diverse set of case studies and ultimately a diagnostic analysis. The proposed framework is not intended as a device to conduct a detailed analysis of specific cases. We assume that much can be learned from the comparison across a larger number of diverse cases. Ultimately, the purpose of this cross-comparison is to analyze the effectiveness of participatory processes and their elements. This does not undermine the need for in-depth analysis of specific cases, which is both necessary and essential when studying participatory processes. Both approaches are complementary. 
Author-produced version of the article published in Journal of Environmental Management, 2015, N¹57, p.84-95. The original publication is available at http://www.sciencedirect.com

Doi:10.1016/j.jenvman.2015.04.012

The framework is intended to be informed by any stakeholder or group of stakeholders having sufficient insights on the participatory process of interest to be able to inform the variables. Variables are defined here as elements or criteria used to describe participatory processes. For each variable, informants can choose among a list of different "options" or values. Informants will preferably be stakeholders involved in the process, its design, implementation and/or evaluation. Identity of the informant is to be taken into account in any analysis or cross-comparison of results.

Section 2 describes the development of the framework for the Comparison of Participatory Processes (COPP). Section 3 highlights three monitoring and evaluation (M\&E) elements requiring clarification when informing the framework. Section 4 details a COPP framework analysis of five case studies across Asia and Africa. Finally, we analyze the cross-comparative results and evaluate the COPP framework performance. The synthesized COPP framework, presented as a "ready-to-use" assessment template, is detailed in Annex 1.

\section{Framework for describing, diagnosing and comparing}

\section{participatory processes}

The framework for the Comparison of Participatory Processes (COPP) is composed of three dimensions, synthesized from literature based insights. The proposed COPP dimensions represent four literature-derived cohorts of theorists and practitioners contributing to the corpus of scholarship. The first cohort represents scholars who identify variables related to the management of coupled social-environmental systems and institutions (e.g. Folke et al., 2005; Herrfahrdt-Pähle \& Pahl-Wostl, 2012; Ostrom, 2005; Saleth, 2006; Scott, 2001). The 
Author-produced version of the article published in Journal of Environmental Management, 2015, №157, p.84-95. The original publication is available at http://www.sciencedirect.com

Doi:10.1016/j.jenvman.2015.04.012

second cohort includes documentation of scholars from the field of policy-making,

governance and policy assessment (e.g. Dovers \& Hussey, 2013; Dovers, 2003; Lankford, 2008; Sabatier, 1988) that focus on the decision-making process, its institutionalization and assessment. Even readers interested in participatory processes with foci other than social, environmental and policy design will find valuable insights in the literature of these two cohorts. A third cohort draws from management science and is concerned with evaluation in general, and more specifically the evaluation of collaborative endeavors (e.g. Bellamy et al., 2001; Byrne, 2013; Conley \& Moote, 2003; Couix, 1997; William, 2007). Authors in this cohort are focused on evaluation methods, principles and guidelines. Finally, the most abundant reviewed literature concerns public participation, in particular the evaluation of public participation processes and methods (e.g. Beierle \& Cayford, 2002; Innes \& Booher, 1999; Rowe \& Frewer, 2000, 2004). The added-value of these different cohorts for the COPP framework is described in sections 2 and 3 of this paper.

This paper considers only publications with explicit variables that can contribute to the assessment of participatory processes. Most existing approaches and variables were developed to describe or assess a specific participatory process, not necessarily to compare a diverse set of processes. The review of existing frameworks reveals that many variables are similar, flagging the potential of a generalizable assessment framework.

We describe in detail the three assessment dimensions of the COPP framework: context, process attributes, and outputs, outcomes and impacts. One perspective reliant on framework parsimony might limit assessment to process characteristics and outputs and outcomes. However, many authors suggest that contextual aspects are critical for understanding outcomes (e.g. Beierle \& Cayford, 2002; Cleaver \& Franks, 2005; Midgley et al., 2013; Ostrom, 2005; Sabatier, 1988). We also contend that a clear articulation of 
Author-produced version of the article published in Journal of Environmental Management, 2015, N¹57, p.84-95. The original publication is available at http://www.sciencedirect.com

Doi:10.1016/j.jenvman.2015.04.012

standardized monitoring and evaluation (M\&E) objectives, team composition and methods are necessary to promote independent replication and validation.

A number of participatory processes evaluation frameworks exist with similar goals (e.g. Abelson et al., 2003; Rosener, 1981; Rowe \& Frewer, 2000). Often, these frameworks focus on the process and/or its outcomes, without detailing the context dimension or the M\&E. For example, Krywkow (2009) suggests an approach based on six "intensity criteria" to evaluate to what extent various participatory processes objectives have been reached. He assumes that the M\&E objective is to evaluate the effectiveness of the participatory process in reaching its objectives. We argue for a broader diversity of M\&E objectives, which may differ from process objectives. For example, the goal of the participatory process may be to develop a policy, while the M\&E may aim to jointly assess whether the process also contributed to building the capacity of the stakeholders in implementing this policy. In other cases, proposed frameworks may be method-oriented (e.g. Midgley et al., 2013) or discipline-specific (e.g. Ostrom, 2005). The COPP framework aims at being used across participatory processes characterized by diverse contexts, M\&E objectives, methods and disciplines.

\subsection{The context dimension}

The implementation of a specific participatory process method can lead to different outcomes due to differences in contextual circumstances (Buysse et al., 1999; Champion \& Wilson, 2010; Checkland \& Scholes, 1990; McAllister, 1999; McGurk et al., 2006; Morgan, 2001; Murphy-Berman et al., 2000; Rowe \& Frewer, 2000, 2004; Warburton et al., 2007; White, 2006 cited in Midgley et al., 2013). This can be due to particular methods not being 
Author-produced version of the article published in Journal of Environmental Management, 2015, N¹57, p.84-95. The original publication is available at http://www.sciencedirect.com

Doi:10.1016/j.jenvman.2015.04.012

effective across all contexts or due to particular process steps triggering different dynamics.

The same method utilized by the same practitioner or researcher can succeed or fail depending on the complexities and dynamics of the situation. Most scholars recognize the importance of the context by advocating for context-specific process designs. Some aggregate contextual drivers, for instance as the "influence of the external environment" (Champion \& Wilson, 2010). Few, however, list formalized contextual variables.

Indeed, there is a wide range of contextual factors with the potential to affect participatory processes and their outcomes. Identifying influencing factors a priori can be difficult. Nevertheless, our aim here is not analytical but comparative. Thus, key context variables are needed to distinguish contexts into broad categories. We include five variables that come with empirical evidence to confirm their relevance. The options associated with these five variables are listed in Annex 1.

The first variable of the context dimension of the COPP Framework is the "target system elements". Even though this variable is not explicitly listed in the literature, we argue that it allows for an important categorization and a deeper understanding of the system elements which the process aims to target. Target system elements can be natural or environmental, such as water and forests, economic, social, political, urban, health, technological and/or educational.

Many scholars identify "levels of governance influencing target system elements" as a critical variable, using different terms but with similar meanings: "shared jurisdiction" (Beierle \& Konisky, 2000) or "scale of issue" (Perez et al., 2011). This variable is defined by the level of decision-making influencing the target system. For instance, individually managed wells may only be influenced by decisions taken at the village level. We apply the 
Author-produced version of the article published in Journal of Environmental Management, 2015, N¹57, p.84-95. The original publication is available at http://www.sciencedirect.com

Doi:10.1016/j.jenvman.2015.04.012

terminology used for multi-level approaches to delineate the three options for this variable: macro (national or larger), meso (subnational) and/or micro (village or group of villages).

The third variable refers to "other past/present intervention attempts" to distinguish contexts in which many initiatives have been implemented already from other situations where only a few or even no other initiatives have been implemented (Burton, Goodlad, \& Croft, 2006; Champion \& Wilson, 2010; Midgley et al., 2013; Ostrom, 2005).

The majority of scholars working on participatory processes identify the relevance of "preexisting relationships among participants" as a critical variable. Allison \& Hobbs (2006), Bellamy et al. (2001), Chess \& Purcell (1999) and Cumming (2000) refer to the social context broadly and Foley et al. (2003) refer to social "natural resources". Others more specifically mention variables linked to conflict and mistrust as hindering contextual effects for participatory processes (Beierle \& Cayford, 2002; Beierle \& Konisky, 2000; Bellamy et al., 2001; Branch \& Bradbury, 2006; Brocklesby, 2009; Jackson \& Keys, 1984; Kelly \& Van Vlaenderen, 1995; Ong, 2000; Ostrom, 2005; Perez et al., 2011; Webler \& Tuler, 2002). The COPP Frameworks adopts the options suggested by Beierle \& Cayford (2002) to describe the pre-existing relationships among participants: no pre-existing relationship, high degree of mistrust and conflict, moderate trust and conflict or good pre-existing relationships and trust.

Finally, the fifth variable refers to "participants' understanding of target system elements". Scholarly examination across diverse disciplines and fields of inquiry have led to the distinction between two aspects of knowledge: facts, considered as a local and scientific knowledge system, and values, or the moral and ethical values and norms that condition how facts are perceived, in the tradition of Brown (1984) and More et al. (1996). 
Author-produced version of the article published in Journal of Environmental Management, 2015, N¹57, p.84-95. The original publication is available at http://www.sciencedirect.com

Doi:10.1016/j.jenvman.2015.04.012

Participants' understanding of the target system elements, participants' perception of their own knowledge about the system, and the degree of acceptance assume a central role in the majority of reviewed participatory process case studies. Consistent with the COPP principles of standardization and tractability, this variable has been synthesized into two detectable attributes which distinguish whether participants state they understand, or not, target system elements.

\subsection{The participatory process dimension}

Methodological and procedural choices constitute the core of our comparative diagnostic.

Which methods were used? How were the participants selected? Who instigated the process? Many of those questions, however, often remain hidden in descriptions and assessments of participatory processes. Detailing the way the process is translated from abstract to praxis is essential in describing and comparing cases. When combined with enabling and constraining contextual factors, comparisons can reveal either principle patterns or procedural or methodological choices that lead to outcomes more aligned with target objectives.

Fourteen variables were identified as relevant for the process dimension. They were drawn predominantly from the major steps to be considered when designing a participatory process and from the main elements considered in in-depth descriptions of specific processes. The options associated with these fourteen variables are listed in Annex 1.

The first variable is the "participatory process objectives" which was identified by many authors including Beierle \& Cayford (2002), Beierle \& Konisky (2000), Bellamy et al. (2001), 
Author-produced version of the article published in Journal of Environmental Management, 2015, N¹57, p.84-95. The original publication is available at http://www.sciencedirect.com

Doi:10.1016/j.jenvman.2015.04.012

Lynam et al. (2007), Ostrom (2009) and Tippett et al. (2007). The combination of the options

suggested in these frameworks as well as the experience of the authors on participatory processes allowed the identification of four main options for this variable: exploring decision-making options, improving stakeholders' systems understanding, resolving or avoiding conflicts and gathering knowledge. We acknowledge that the complexity of participatory processes often involves a multiplicity of contested and evolving process objectives. We understand here "participatory process objectives" as the "official" or "stated" objectives of the process once framing discussions and trade-offs have taken place among participants. The multiplicity of objectives is reflected in the possibility to select multiple options for this variable.

The "instigator(s) of the process" is explicitly or implicitly mentioned by several authors including Beierle \& Konisky (2000), Chess \& Purcell (1999) and Warner (1997). Instigators of the process include stakeholders who first triggered the process, who had the idea and mobilized other stakeholders. They can be: donor or development agency representatives, researchers, decision-makers or governmental stakeholders, civil society and/or private sector representatives. These options are based on Beierle \& Cayford (2002), Michener (1998) and Okali et al. (1994).

The third variable "team" concerns the stakeholders who are designing, implementing and facilitating the participatory process. This variable is generally not explicitly listed in other work. However, description of the composition of the team leading the participatory process is typically provided in case descriptions. The same options were applied as the "instigator(s) of the process" variable. 
Author-produced version of the article published in Journal of Environmental Management, 2015, N¹57, p.84-95. The original publication is available at http://www.sciencedirect.com

Doi:10.1016/j.jenvman.2015.04.012

Similarly, the origin of the team, in terms of place and professional background, impacts their expectations towards the participatory process and is often linked to the success of the process (e.g. Chess \& Purcell, 1999; Daniell, 2012; Godschalk \& Stiftel., 1981; Renn et al., 1995). Team members can come from the area and/or affect or be affected by target system elements, for example if they are decision-makers with a mandate in the area of concern. They can also be external to the area, for example in the case of international researchers or non-governmental organizations.

The "selection of the participants" is frequently introduced in participatory processes evaluation frameworks as the "representativeness" of participants (e.g. Berry et al., 1984; Crosby et al., 1986; Petts, 1995, 2001; Rowe \& Frewer, 2000; Rowe et al., 2004). However, we prefer "selection of the participants" for two reasons: first, the process under consideration may not aim at selecting participants who are representative of the broader population and two, even if it does, in order to be able to infer results to the broader population, representativeness needs to be rigorous and defensible. This variable corresponds to the stakeholders who made the ultimate choice of who would be invited to participate in the process and actively sent the invitations. It can be the team or a third party, the donor or government for instance. The selection of options for the "selection of the participants" variable is adapted from Fung $(2003,2006)$.

The "size of the group" is identified as a criteria by several authors working on group cohesion, group performance and small group theory (e.g. Annese \& Traetta, 2012; Carron \& Spink, 1995; Indik, 1965; Mullen et al., 1987; Slater, 1958; Thomas \& Fink, 1963). Therefore we decided to include it in the COPP Framework. The "group" is defined here as all participants involved in the process, excluding the team. 
Author-produced version of the article published in Journal of Environmental Management, 2015, N¹57, p.84-95. The original publication is available at http://www.sciencedirect.com

Doi:10.1016/j.jenvman.2015.04.012

The work of Fung $(2003,2006)$ was used as a basis for the seventh variable "level of participants' process expectations" to which we added the notion of confidence in the process outlined by Beierle \& Konisky (2000) (drawn from Gurtner-Zimmermann, 1996; Landre \& Knuth, 1993). Options are defined as "high" when participants believe that the process can really change the target system or as "low" otherwise.

Many scholars consider the engagement of specific governance levels: lead agency (Beierle \& Konisky, 2000), local government (Conley \& Moote, 2003) and higher authority (MacNair et al., 1983). Therefore, we include "governance level(s) engaged" as a variable. As participatory processes are increasingly engaging multiple levels of governance, the options selected reflect this multiplicity.

The ninth variable "length of the process" is not often explicitly raised in the literature but systematically used in description of specific cases, suggesting its relevance in successfully implementing participatory processes. Options identified for this variable are: less than a year, one to five years or more than five years.

The tenth variable "number of events" is suggested by Fung $(2003,2006)$, MacNair et al. (1983) and Ostrom (2005). It is defined by the number of times participants are invited to give their opinion and make collective decisions. Events include, but are not limited to, workshops, meetings and gatherings, in person or not (e.g. online). Rather than broad options as identified in previous literature (single / finite / infinite or regular / limited in time / institutional guarantees to allow repetition), we argue that greater comparison can be achieved by specifying the number of events which took place within the process. 
Author-produced version of the article published in Journal of Environmental Management, 2015, N¹57, p.84-95. The original publication is available at http://www.sciencedirect.com

Doi:10.1016/j.jenvman.2015.04.012

The eleventh variable "degree of participant retention" relates to the extent to which the group of participants remains constant or changes over the different participatory events. Four options were delineated based on past case study examples: less than $24 \%, 25$ to $49 \%$, 50 to $74 \%$ or more than $75 \%$ of participants attended the whole process.

Concerning the "setting of exchange" variable, we used the options listed by Barreteau et al. (2010, drawn from Bots \& van Daalen, 2008) and extrapolated them to participatory processes in general. "Setting of exchange" is defined here as the ways in which participants are involved within participatory processes. For example, participants may at times be asked to give their personal opinion and be therefore involved individually. At other times, they might be involved as a homogeneous group, for example through plenary meetings. Finally, sub-groups may be formed, when the team takes into account the heterogeneity of participants, for example by grouping women together because they feel inhibited by the presence of men in the same group. The "setting of exchange" determines who will interact with whom, and how. Often, an alternation of different settings takes place within the same process, reflected by the possibility to select multiple options for this variable in the framework.

The "degree of participation" is one of the most addressed categories for process description in the literature. Different typologies distinguish degrees to which stakeholders are engaged, the most cited one being Arnstein's (1969) "ladder of participation". Numerous alternative terms have been suggested for the different rungs of this ladder (e.g. Goetz \& Gaventa, 2001; Lawrence, 2006; Pretty et al., 1995; Pretty, 1995), as well as alternative concepts to describe degrees or levels of participation (Beierle \& Konisky, 2000; Biggs, 1989; Davidson, 1998; Farrington, 1998; Fung, 2003, 2006) or their roles or tasks (MacNair et al., 1983; Rowe \& Frewer, 2000; Rowe et al., 2004). Yet most of the options describing the 
Author-produced version of the article published in Journal of Environmental Management, 2015, N¹57, p.84-95. The original publication is available at http://www.sciencedirect.com

Doi:10.1016/j.jenvman.2015.04.012

variable are broad and we prefer a concrete listing of stages in which participants may be involved, as explored by Daniell (2012). This variable includes participants in the process only, excluding team members.

The final variable of the process dimension is the participatory "methods and tools" employed during the process. Most typologies of participation suggest methods that are appropriate to different levels of engagement (Arnstein, 1969; Biggs, 1989; Pretty et al., 1995; Pretty, 1995; Richards et al., 2004). Rowe \& Frewer (2000) categorize the methods according to their goal (communicate, consult, participate). Many other scholars have reviewed a wide range of tools and methods (Burton et al., 2004; Chambers, 2002; Davies, 1997; DFID, 2002; Galpin et al., 2000; IAPP, 2004; Involve, 2005; Jayakaran, 2003; Mayoux, 2005; Mikkelsen, 2005; New Economics Foundation, 1998; OECD, 2001; Pretty et al., 1995; Rennie \& Singh, 1996; Rietbergen-McCracken \& Narayan, 1996; Scottish Parliament, 2004; Shah et al., 1999; Tippett et al., 2007; Wates, 2000). Based on this literature four options were identified for this variable, as listed in Annex 1: non-computerized model(s), computerized model(s), surveys and studies, and visioning, foresight, scenario-building.

\subsection{The outputs, outcomes and impacts dimension}

The range of potential outputs, outcomes and impacts of participatory processes can be wide including tangible and intangible, short and long term or environmental and social. We consider in this dimension the three elements usually distinguished by analysts in this field: outputs, as immediate products of the process; outcomes, as effects of the process on the behavior of key actors in the relevant systems; and impacts, as the extent to which the participatory process play influential roles in solving or at least alleviating the concerns leading to its creation (adapted from Young, 2008). Indeed, the effects of the process 
Author-produced version of the article published in Journal of Environmental Management, 2015, N¹57, p.84-95. The original publication is available at http://www.sciencedirect.com

Doi:10.1016/j.jenvman.2015.04.012

depend on various factors, including the objective of the process and the objective of the

M\&E. The COPP Framework does not aim to detail all potential outputs, outcomes and impacts of specific participatory processes, but identifying major changes which may be expected from such processes for diagnostic and comparative purposes.

The outputs, outcomes and impacts dimension includes six variables. Various typologies exist for classifying the impacts of participatory processes. Some are based on the timing (short, middle and long term), others on the type of impact (e.g. social, environmental, political) or on the nature of impacts (tangible or intangible). The variables chosen here try to define broad types of impacts (on the actual participants and on actions implemented by participants) while taking into account their temporal, spatial and social scales. The options associated with these four variables are listed in Annex 1.

The "main outputs" of the participatory process are generally quite straightforward and are strongly linked to the objectives of the process. This variable comprises the immediate tangible products of the process, which are generally easy to monitor and appear in the short term, during or right after the end of the process. Outputs may include new, revised or dismissed development plans, policies, investments, technologies, laws, agreements, memorandum of understanding, terms of reference and models. This variable is not necessarily listed in existing frameworks but identified systematically in all descriptions of empirical cases. The list of options proposed should be applicable across various fields of application.

The "impact on participants" variable encompasses the intangible outcomes of the process on participating stakeholders. Many recent researchers focused on the evaluation of participatory processes provide a list of options relevant for this variable (e.g. Carr \& 
Author-produced version of the article published in Journal of Environmental Management, 2015, N¹57, p.84-95. The original publication is available at http://www.sciencedirect.com

Doi:10.1016/j.jenvman.2015.04.012

Halvorsen, 2001; Conley \& Moote, 2003; Ferrand \& Daniell, 2006 summarized in Daniell, 2012; Guston, 1999; Innes \& Booher, 1999; Perez et al., 2011; Webler \& Tuler, 2002). Other authors mention "individual impacts on participants" as one possible impact category, without detailing potential options for describing these impacts (e.g. Einsiedel et al., 2001; GIS, 2011). Others identify specific individual impacts such as Chess \& Purcell (1999), Midgley et al. (2013) and Petts $(1995,2001)$. Options were identified based on this literature review and include reduction of conflict, improved understanding of target system elements, capacity-building, influence on decision, and increased collaboration and trust.

The third variable "impact on actions implemented by participants" is cited specifically by Innes \& Booher (1999). In contrast, some authors mention it as one possible impact category, without detailing options to describe these impacts (e.g. Crosby et al., 1986; Ferrand \& Daniell, 2006; Guston, 1999; Houghton, 1988; Midgley et al., 2013; Perez et al., 2011). Finally Webler \& Tuler (2002) inter alia, identify specific impacts related to participants' actions. We identified that "impact on actions implemented by participants" could be individual behavioral change such as change in daily practices and actions, or collective actions.

There is limited reference in the reviewed papers to the three remaining variables in this dimension, namely "social scale", "spatial extent" and "time scales" of the impacts, and an absence of explicit inclusion in their frameworks. However, relevance of these variables has been empirically established. Processes often target further "extension" either socially (beyond the group of stakeholders involved) or spatially (beyond the target area) by using pilot sites. Therefore, assessment of the social scales and spatial extent of the impacts of the process seemed relevant variables to be included in the COPP Framework. We note that Innes \& Booher (1999) mentions the social scale in their framework. Very few of the authors 
Author-produced version of the article published in Journal of Environmental Management, 2015, N¹57, p.84-95. The original publication is available at http://www.sciencedirect.com

Doi:10.1016/j.jenvman.2015.04.012

reviewed evoke time explicitly as a category in their framework (e.g. Connick \& Innes, 2003;

Midgley et al., 2013). Yet, the "time scale of the impacts" is implicitly mentioned in almost all research on participatory processes, especially those making the distinction between outputs (short term) / outcomes (mid-term) / impacts (long term) or first-order (during the process), second-order (following year or two) and third-order (longer term) effects (e.g. Connick \& Innes, 2003; Young, 2008).

\section{Monitoring and evaluation}

Attention to M\&E methods enables verifiable assessment of process influence at both the individual level and on group crafted outcomes. M\&E provides the analytical foundation to appraise a specific implementation of a participatory process and the reference for future methodological revisions that are aligned with process objectives. However, while participatory approaches have gained some prominence, they are still too rarely rigorously evaluated. Many researchers describe participatory processes and their outcomes without providing details about the M\&E approach employed (Frewer \& Rowe, 2005). M\&E details are critical to compare the efficacy of methods to elicit information sufficiently robust to attribute outcomes to particular participatory interventions.

Three elements are essential to detail to make the M\&E transparent. These are: the M\&E objective(s), the M\&E team and the qualitative and quantitative M\&E methods used. Literature on evaluation (e.g. Boyd et al., 2007; Byrne, 2013; Lincoln \& Guba, 1989; Renger et al., 2011; Rossi et al., 1999; William, 2007) and guidebooks on social research (e.g. Babby, 2004; Creswell, 1994; Crotty, 1998) were particularly useful resources for identifying these elements. 
Author-produced version of the article published in Journal of Environmental Management, 2015, N¹57, p.84-95. The original publication is available at http://www.sciencedirect.com

Doi:10.1016/j.jenvman.2015.04.012

First, M\&E objective(s) can differ from the objective(s) of the process. Yet, both are too often confounded. Various scholars emphasize the importance of clarifying M\&E objective(s) (e.g. Conley \& Moote, 2003; Midgley et al., 2013; Syme \& Sadler, 1994). Based on the work of Bellamy et al. (2001) as well as authors examining the assessment of the quality of the participatory process (e.g. Ashford, 1984; Fiorino, 1990; Peelle et al., 1996; Renn et al., 1995) and authors working on interest-oriented evaluations (e.g. Sewell \& Phillips, 1979), we argue that M\&E objective(s) can be:

- Donor-oriented: making sure that the process respected the allocated time and costs,

- Beneficiary-oriented: making sure that the intervention/process reached its objective(s), and/or

- Research-oriented: specific M\&E objective(s) (e.g. measuring a specific outcome). Involvement of various stakeholders in the M\&E generates a multiplicity of perspectives and objectives in terms of what the M\&E should entail, and how and when it should be carried out. Clarifying M\&E objectives implies discussions and trade-offs and a strong "framing" moment when "boundary judgments" (Midgley, 1997; Ulrich, 1983; William, 2007) are made about what is "in" and what is "out" of the M\&E.

Second, the M\&E team may be part of, or external to, the team organizing and facilitating the participatory process. Evaluators may be representatives of a development agency, researchers, professional independent consultants or participants in the process. Identity of the evaluator(s) may influence M\&E implementation, data analysis and interpretation (Conley \& Moote, 2003; Midgley, 2007). It is therefore essential to clarify who M\&E team members are and what their relationship with the team and the participants is. 
Author-produced version of the article published in Journal of Environmental Management, 2015, N¹57, p.84-95. The original publication is available at http://www.sciencedirect.com

Doi:10.1016/j.jenvman.2015.04.012

Third, the choice of M\&E methods is particularly strategic when monitoring and evaluating a participatory process as M\&E methods may impact the results of the study and its quality, validity, and credibility (Patton 1999). M\&E methods are defined here as the techniques or procedures used to obtain and collate raw data on the participatory process. Listings of qualitative methods are quite extensive in social research guidebooks (e.g. Midgley et al., 2013; Syme \& Sadler, 1994). They include participant observation, non-participant observation, field notes, reflexive journals or logbooks, interviews and focus-groups, literature review, questionnaires and expectations. Despite limited quantitative methods employed in participatory processes, they are increasingly listed in recent social research guidebooks. They include census or survey (face to face or self-administered), questionnaires, polls and counting of instances of occurrence in participatory events (e.g. speakers having a say, certain body language expressions, issues raised). Mixed-methods approaches are increasingly used for participatory processes (e.g. Daniell, 2012; Poteete et al., 2010; Smajgl \& Ward, 2013).

Section 4 describes the application of the COPP Framework to five case studies across a diverse set of empirical situations.

\section{Case study application results}

The COPP framework was applied to five case studies: three located in the Mekong basin in Southeast Asia and two in eastern Africa. Some context variables are similar as all five studies focused on environmental issues with natural resources as target system elements. Table 1 shows differences for the levels of governance influencing the target system elements, the number of previous projects addressing the same issues in the same region 
Author-produced version of the article published in Journal of Environmental Management, 2015, №157, p.84-95. The original publication is available at http://www.sciencedirect.com

Doi:10.1016/j.jenvman.2015.04.012

and participants' understanding of target system elements. Additionally, a relationship

Table 1. Application of the COPP Framework to five case studies - Context dimension

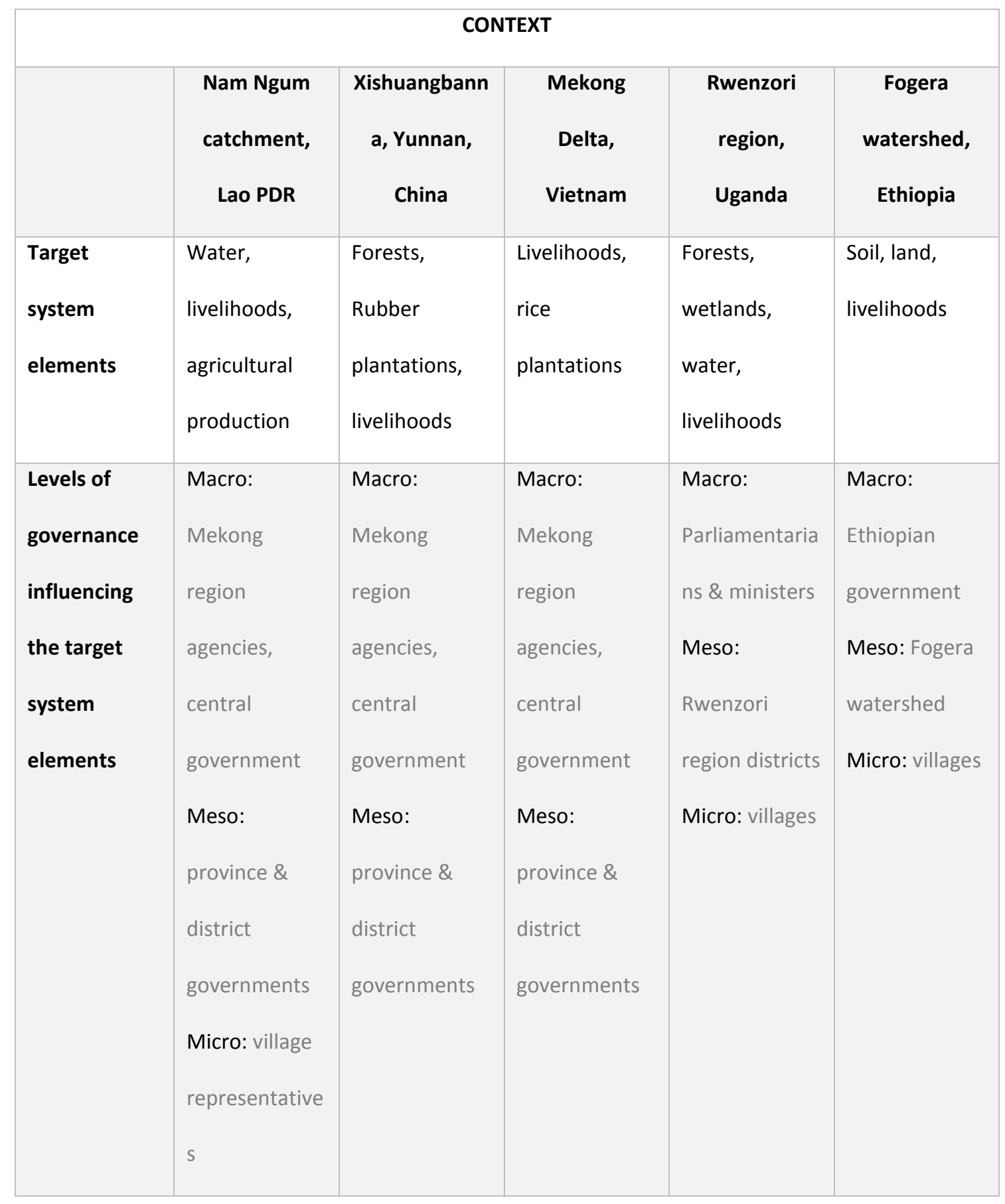


Author-produced version of the article published in Journal of Environmental Management, 2015, N¹57, p.84-95. The original publication is available at http://www.sciencedirect.com

Doi:10.1016/j.jenvman.2015.04.012

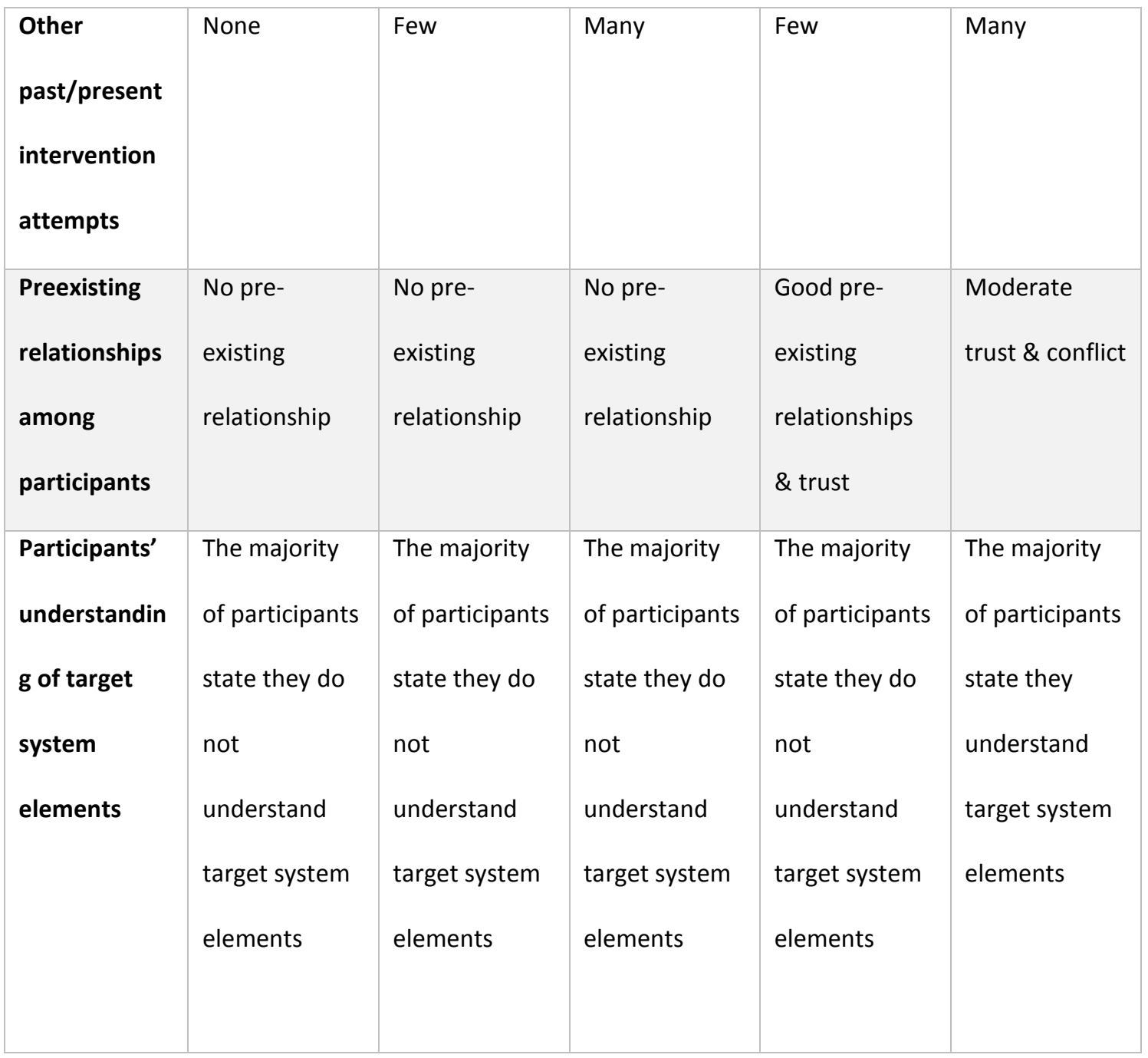

Table 2 lists the participatory process variables for the five case studies. While all five case studies started with similar goals, included multiple events and similar group sizes, all other variables vary.

Table 2. Application of the COPP Framework to five case studies - Process dimension

\section{PARTICIPATORY PROCESS}

\begin{tabular}{|l|l|l|l|l|l|}
\hline & Lao PDR & China & Vietnam & Uganda & Ethiopia \\
\hline Participatory & Improve & Improve & Improve & Exploring & Exploring \\
\hline
\end{tabular}


Author-produced version of the article published in Journal of Environmental Management, 2015, №157, p.84-95. The original publication is available at http://www.sciencedirect.com

Doi:10.1016/j.jenvman.2015.04.012

\begin{tabular}{|c|c|c|c|c|c|}
\hline $\begin{array}{c}\text { process } \\
\text { objectives }\end{array}$ & $\begin{array}{l}\text { participants' } \\
\text { system } \\
\text { understandin } \\
\text { g }\end{array}$ & $\begin{array}{l}\text { participants' } \\
\text { system } \\
\text { understandin } \\
\text { g }\end{array}$ & $\begin{array}{c}\text { participants' } \\
\text { system } \\
\text { understandin } \\
\text { g }\end{array}$ & $\begin{array}{l}\text { decision- } \\
\text { making } \\
\text { options, } \\
\text { improve } \\
\text { participants' } \\
\text { system } \\
\text { understandin } \\
\text { g }\end{array}$ & $\begin{array}{l}\text { decision- } \\
\text { making } \\
\text { options, } \\
\text { improve } \\
\text { participants' } \\
\text { system } \\
\text { understandin } \\
\text { g }\end{array}$ \\
\hline $\begin{array}{c}\text { Instigator(s) } \\
\text { of the } \\
\text { process }^{\mathrm{a}}\end{array}$ & $\begin{array}{l}\text { Donor, } \\
\text { decision- } \\
\text { makers } \\
\text { (MoNRE Lao } \\
\text { PDR) }\end{array}$ & $\begin{array}{l}\text { Donor, } \\
\text { researchers } \\
\text { (ICRAF China) }\end{array}$ & $\begin{array}{l}\text { Donor, } \\
\text { decision- } \\
\text { makers } \\
\text { (DoNRE } \\
\text { Vietnam), } \\
\text { researchers } \\
\text { (Uo Can Tho) }\end{array}$ & $\begin{array}{l}\text { Donor } \\
\text { (European } \\
\text { Commission), } \\
\text { researchers } \\
\text { (community } \\
\text { university) }\end{array}$ & $\begin{array}{l}\text { Donor } \\
\text { (European } \\
\text { Commission), } \\
\text { researchers } \\
\text { (IWMI and } \\
\text { ILRI) }\end{array}$ \\
\hline Team $^{b}$ & $\begin{array}{l}\text { Decision- } \\
\text { makers } \\
\text { (MoNRE Lao } \\
\text { PDR), } \\
\text { researchers } \\
\text { (IWMI, CSIRO) }\end{array}$ & $\begin{array}{l}\text { Researchers } \\
\text { (ICRAF China, } \\
\text { CSIRO) }\end{array}$ & $\begin{array}{l}\text { Decision- } \\
\text { makers } \\
\text { (DoNRE } \\
\text { Vietnam), } \\
\text { researchers } \\
\text { (Uo Can Tho } \\
\text { CSIRO, } \\
\text { SIWRR) }\end{array}$ & $\begin{array}{l}\text { Researchers } \\
\text { (community } \\
\text { university, } \\
\text { IRSTEA) }\end{array}$ & $\begin{array}{l}\text { Researchers } \\
\text { (ILRI, IWMI, } \\
\text { IRSTEA) }\end{array}$ \\
\hline
\end{tabular}

\footnotetext{
${ }^{a}$ MoNRE $=$ Ministry of Natural Resources and Environment ICRAF = International Centre for Research in Agroforestry DoNRE = Department of Natural Resources and Environment IWMI = International Water Management Institute ILRI = International Livestock Research Institute b IRSTEA = French National Research Institute of Science and Technology for Environment and Agriculture CSIRO = Commonwealth Scientific and Industrial Research Organisation SIWRR = Southern Institute of Water Resources Research
} 
Author-produced version of the article published in Journal of Environmental Management, 2015, N¹57, p.84-95. The original publication is available at http://www.sciencedirect.com

Doi:10.1016/j.jenvman.2015.04.012

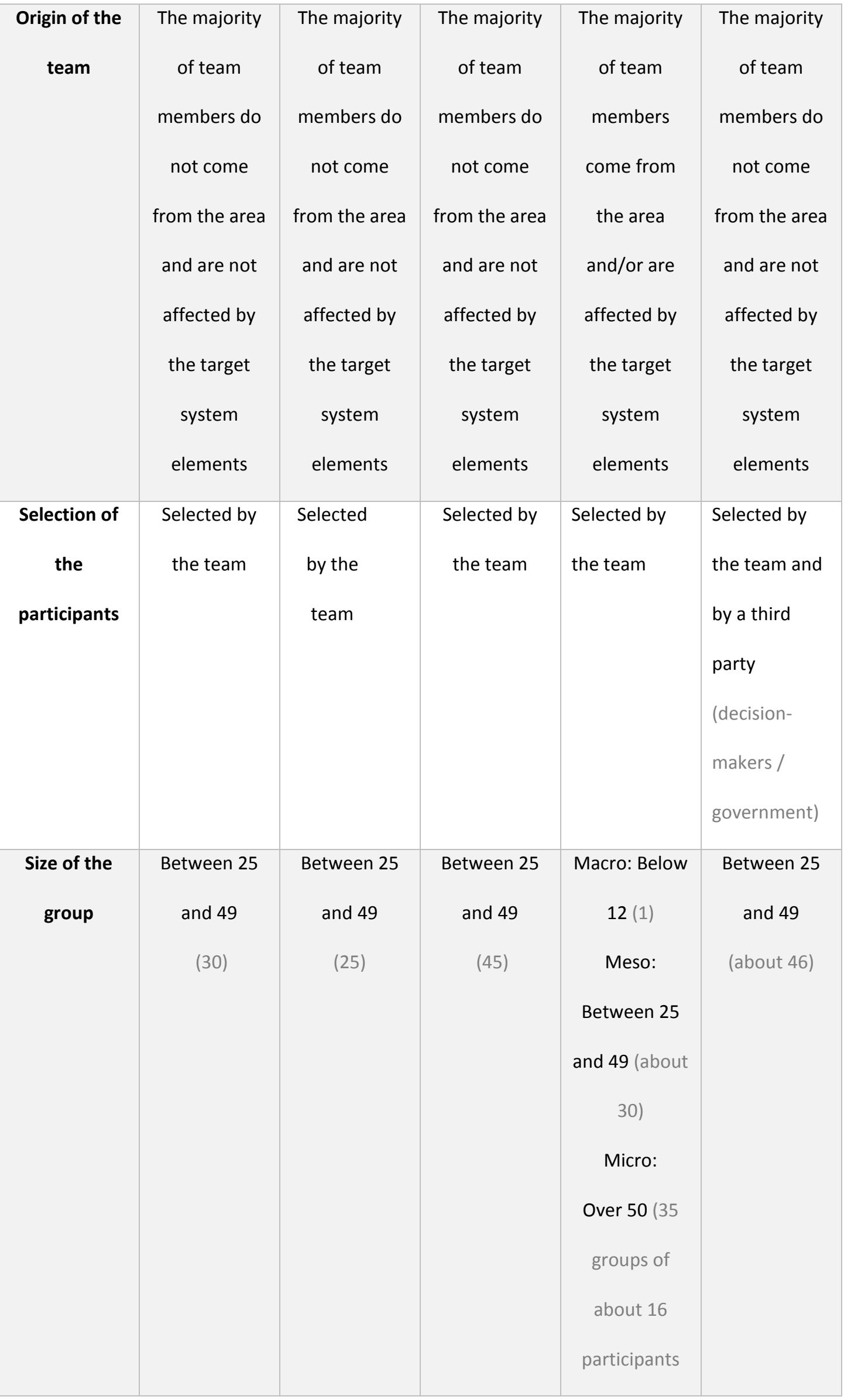


Author-produced version of the article published in Journal of Environmental Management, 2015, №157, p.84-95. The original publication is available at http://www.sciencedirect.com

Doi:10.1016/j.jenvman.2015.04.012

\begin{tabular}{|c|c|c|c|c|c|}
\hline & & & & each) & \\
\hline $\begin{array}{c}\text { Level of } \\
\text { participants' } \\
\text { process } \\
\text { expectations }\end{array}$ & Low & Low & Low & Low & High \\
\hline $\begin{array}{c}\text { Governance } \\
\text { level(s) } \\
\text { engaged }\end{array}$ & $\begin{array}{c}\text { Multiple } \\
\text { levels }\end{array}$ & $\begin{array}{c}\text { Multiple } \\
\text { levels }\end{array}$ & $\begin{array}{l}\text { Multiple } \\
\text { levels }\end{array}$ & $\begin{array}{c}\text { Multiple } \\
\text { levels }\end{array}$ & Single level \\
\hline $\begin{array}{l}\text { Length of } \\
\text { process }\end{array}$ & $\begin{array}{l}1 \text { to } 5 \text { years } \\
\text { (2.5 years) }\end{array}$ & $\begin{array}{l}1 \text { to } 5 \text { years } \\
\text { (2.5 years) }\end{array}$ & $\begin{array}{c}1 \text { to } 5 \text { years } \\
\text { (3 years) }\end{array}$ & $\begin{array}{l}1 \text { to } 5 \text { years } \\
\text { (16 months) }\end{array}$ & $\begin{array}{l}\text { Less than a } \\
\text { year (10 } \\
\text { months) }\end{array}$ \\
\hline $\begin{array}{c}\text { Number of } \\
\text { events }\end{array}$ & $\begin{array}{l}\text { Multiple } \\
\text { events } \\
\text { (5 workshops) }\end{array}$ & $\begin{array}{l}\text { Multiple } \\
\text { events } \\
\text { (5 workshops) }\end{array}$ & $\begin{array}{l}\text { Multiple } \\
\text { events } \\
\text { (6 workshops) }\end{array}$ & $\begin{array}{l}\text { Macro: single } \\
\text { event } \\
\text { Meso: } \\
\text { multiple } \\
\text { events (4 } \\
\text { workshops) } \\
\text { Micro: } \\
\text { multiple } \\
\text { events } \\
\text { (7 to } 8 \\
\text { workshops } \\
\text { per group) }\end{array}$ & $\begin{array}{l}\text { Multiple } \\
\text { events } \\
\text { (3 workshops) }\end{array}$ \\
\hline $\begin{array}{c}\text { Degree of } \\
\text { participation } \\
\text { retention }\end{array}$ & $\begin{array}{l}50 \text { to } 74 \% \text { of } \\
\text { participants } \\
\text { attended the } \\
\text { whole process }\end{array}$ & $\begin{array}{l}50 \text { to } 74 \% \text { of } \\
\text { participants } \\
\text { attended the } \\
\text { whole process }\end{array}$ & $\begin{array}{l}50 \text { to } 74 \% \text { of } \\
\text { participants } \\
\text { attended the } \\
\text { whole process }\end{array}$ & $\begin{array}{l}\text { Less than } 24 \% \\
\text { of } \\
\text { participants } \\
\text { attended the }\end{array}$ & $\begin{array}{l}25 \text { to } 49 \% \text { of } \\
\text { participants } \\
\text { attended the } \\
\text { whole process }\end{array}$ \\
\hline
\end{tabular}


Author-produced version of the article published in Journal of Environmental Management, 2015, №157, p.84-95. The original publication is available at http://www.sciencedirect.com

Doi:10.1016/j.jenvman.2015.04.012

\begin{tabular}{|c|c|c|c|c|c|}
\hline & & & & whole process & \\
\hline $\begin{array}{l}\text { Setting of } \\
\text { exchange }\end{array}$ & $\begin{array}{l}\text { Participants } \\
\text { are involved } \\
\text { as a } \\
\text { heterogeneou } \\
\text { s group }\end{array}$ & $\begin{array}{l}\text { Participants } \\
\text { are involved } \\
\text { as a } \\
\text { heterogeneou } \\
\text { s group }\end{array}$ & $\begin{array}{l}\text { Participants } \\
\text { are involved } \\
\text { as a } \\
\text { heterogeneou } \\
\text { s group }\end{array}$ & $\begin{array}{l}\text { Participants } \\
\text { are involved } \\
\text { alternatively } \\
\text { individually, } \\
\text { as a whole } \\
\text { group and as } \\
\text { a } \\
\text { heterogeneou } \\
\text { s group }\end{array}$ & $\begin{array}{l}\text { Participants } \\
\text { are involved } \\
\text { alternatively } \\
\text { individually, } \\
\text { as a whole } \\
\text { group and as } \\
\text { a } \\
\text { heterogeneou } \\
\text { s group }\end{array}$ \\
\hline $\begin{array}{c}\text { Degree of } \\
\text { participation }\end{array}$ & $\begin{array}{l}\text { - (co-) } \\
\text { selection of } \\
\text { participants } \\
\text { - (co-) M\&E } \\
\text { design } \\
\text { (co-) } \\
\text { selection of } \\
\text { M\&E } \\
\text { methods } \\
\text { (co-) } \\
\text { analysis of } \\
\text { results } \\
\text { rommunica of }\end{array}$ & $\begin{array}{l}\text { - (co-) } \\
\text { selection of } \\
\text { participants } \\
\text { - (co-) M\&E } \\
\text { design } \\
\text { (co-) } \\
\text { selection of } \\
\text { M\&E } \\
\text { methods } \\
\text { (co-) } \\
\text { analysis of } \\
\text { results } \\
\text { results }\end{array}$ & $\begin{array}{l}\text { - (co-) } \\
\text { selection of } \\
\text { participants } \\
\text { - (co-) M\&E } \\
\text { design } \\
\text { (co-) } \\
\text { selection of } \\
\text { M\&E } \\
\text { methods } \\
\text { (co-) } \\
\text { analysis of } \\
\text { results } \\
\text { results }\end{array}$ & $\begin{array}{l}\text { - (co-) } \\
\text { selection of } \\
\text { participants } \\
\text { - (co-) } \\
\text { facilitation } \\
\text { of } \\
\text { participator } \\
\text { y events } \\
\text { (co-) M\&E } \\
\text { design } \\
\text { results } \\
\text { (co-) } \\
\text { selection of } \\
\text { m\&E }\end{array}$ & $\begin{array}{l}\text { - (co-) } \\
\text { selection of } \\
\text { participants } \\
\text { (Co-) } \\
\text { facilitation } \\
\text { of } \\
\text { participator } \\
\text { y events }\end{array}$ \\
\hline
\end{tabular}


Author-produced version of the article published in Journal of Environmental Management, 2015, №157, p.84-95. The original publication is available at http://www.sciencedirect.com

Doi:10.1016/j.jenvman.2015.04.012

\begin{tabular}{|c|c|c|c|c|c|}
\hline $\begin{array}{l}\text { Participatory } \\
\text { methods and } \\
\text { tools }\end{array}$ & $\begin{array}{l}\text { - Visioning } \\
\text { - Computeriz } \\
\text { (hydrologica } \\
\text { I models, } \\
\text { integrated } \\
\text { agent-based } \\
\text { modelling) } \\
\text { - Survey } \\
\text { (Household } \\
\text { survey) }\end{array}$ & $\begin{array}{l}\text { - Visioning } \\
\text { d models } \\
\text { (remote } \\
\text { sensing/ } \\
\text { geographic } \\
\text { information } \\
\text { systems, } \\
\text { integrated } \\
\text { agent-based } \\
\text { modelling) } \\
\text { - Survey } \\
\text { (household } \\
\text { survey) }\end{array}$ & $\begin{array}{l}\text { - Visioning } \\
\text { - Computeriz } \\
\text { ed models } \\
\text { (hydrologica } \\
\text { I models, } \\
\text { integrated } \\
\text { agent-based } \\
\text { modelling) } \\
\text { - Survey and } \\
\text { study } \\
\text { (agricultural } \\
\text { productivity } \\
\text { study, } \\
\text { household } \\
\text { survey) }\end{array}$ & $\begin{array}{l}\text { - Non- } \\
\text { computerize } \\
\text { d model } \\
\text { (role-playing } \\
\text { games) }\end{array}$ & $\begin{array}{l}\text { - Non- } \\
\text { computerize } \\
\text { d model } \\
\text { (role-playing } \\
\text { games) } \\
\text { - Visioning }\end{array}$ \\
\hline
\end{tabular}

All five case studies show positive effects, while the Mekong case study processes suggest even wider impacts beyond the immediate group of participants, as shown in Table 3 .

Table 3. Application of the COPP Framework to five case studies - Outputs, outcomes and impacts dimension

\begin{tabular}{|l|l|c|c|c|c|}
\hline \multicolumn{7}{|c|}{ OUTPUTS, OUTCOMES AND IMPACTS } \\
\hline Main & Lao PDR & China & Vietnam & Uganda & Ethiopia \\
\hline \multirow{2}{*}{ output(s) } & New & Revised policy & New & New & New \\
& development & (payments for & investment & development & development \\
& plan & ecosystem & plan (for & plan & plan \\
\hline
\end{tabular}


Author-produced version of the article published in Journal of Environmental Management, 2015, N¹57, p.84-95. The original publication is available at http://www.sciencedirect.com

Doi:10.1016/j.jenvman.2015.04.012

\begin{tabular}{|c|c|c|c|c|c|}
\hline & (irrigation) & services) & $\begin{array}{l}\text { adapting to } \\
\text { sea-level rise } \\
\text { and salinity } \\
\text { intrusion) }\end{array}$ & $\begin{array}{l}\text { (integrated } \\
\text { natural } \\
\text { resources } \\
\text { management) }\end{array}$ & $\begin{array}{l}\text { (controlled } \\
\text { grazing), } \\
\text { terms of } \\
\text { reference }\end{array}$ \\
\hline $\begin{array}{l}\text { Impact on } \\
\text { participants }\end{array}$ & $\begin{array}{l}\text { - Improved } \\
\text { understandi } \\
\text { ng of target } \\
\text { system } \\
\text { elements } \\
\text { (e.g. of the } \\
\text { impacts of } \\
\text { irrigation on } \\
\text { poverty) } \\
\text { - Capacity- } \\
\text { building } \\
\text { Influence on } \\
\text { decision }\end{array}$ & $\begin{array}{l}\text { - Improved } \\
\text { understandi } \\
\text { ng of target } \\
\text { system } \\
\text { elements } \\
\text { (e.g. of the } \\
\text { impacts of } \\
\text { payments } \\
\text { for } \\
\text { agroforestry } \\
\text { on rubber } \\
\text { decision } \\
\text { production) }\end{array}$ & $\begin{array}{l}\text { - Improved } \\
\text { understandi } \\
\text { ng of target } \\
\text { system } \\
\text { elements } \\
\text { (effectivene } \\
\text { ss of } \\
\text { available } \\
\text { response } \\
\text { options to } \\
\text { dikes) } \\
\text { sea-level } \\
\text { decision } \\
\text { rise) }\end{array}$ & $\begin{array}{l}\text { Improved } \\
\text { understandi } \\
\text { ng of target } \\
\text { system } \\
\text { elements } \\
\text { (e.g. of the } \\
\text { environmen } \\
\text { tal impacts } \\
\text { ts to teach } \\
\text { of } \\
\text { relationship } \\
\text { building } \\
\text { agricultural } \\
\text { comcreapacity- } \\
\text { activities, } \\
\text { biocleansing } \\
\text { ) }\end{array}$ & $\begin{array}{l}\text { - Improved } \\
\text { understandi } \\
\text { ng of target } \\
\text { system } \\
\text { elements } \\
\text { (e.g. of how } \\
\text { to carry out } \\
\text { natural } \\
\text { relationship } \\
\text { resources } \\
\text { puilding } \\
\text { planning, or } \\
\text { collaboratio } \\
\text { how trust, } \\
\text { landscape) } \\
\text { tailor }\end{array}$ \\
\hline
\end{tabular}


Author-produced version of the article published in Journal of Environmental Management, 2015, №157, p.84-95. The original publication is available at http://www.sciencedirect.com

Doi:10.1016/j.jenvman.2015.04.012

\begin{tabular}{|c|c|c|c|c|c|}
\hline & & & & others) & $\begin{array}{l}\text { learning } \\
\text { about each } \\
\text { other's } \\
\text { constraints) }\end{array}$ \\
\hline $\begin{array}{l}\text { Impact on } \\
\text { actions }\end{array}$ & $\begin{array}{l}\text { - Collective } \\
\text { action } \\
\text { (submission } \\
\text { of revised } \\
\text { basin } \\
\text { development } \\
\text { plan) }\end{array}$ & $\begin{array}{l}\text { - Collective } \\
\text { action } \\
\text { (revised } \\
\text { design of } \\
\text { payments } \\
\text { for } \\
\text { agroforestry } \\
\text { in rubber } \\
\text { plantations) }\end{array}$ & $\begin{array}{l}\text { - Collective } \\
\text { action } \\
\text { (revised } \\
\text { land use } \\
\text { plans, } \\
\text { revised } \\
\text { climate } \\
\text { adaptation } \\
\text { plans) }\end{array}$ & 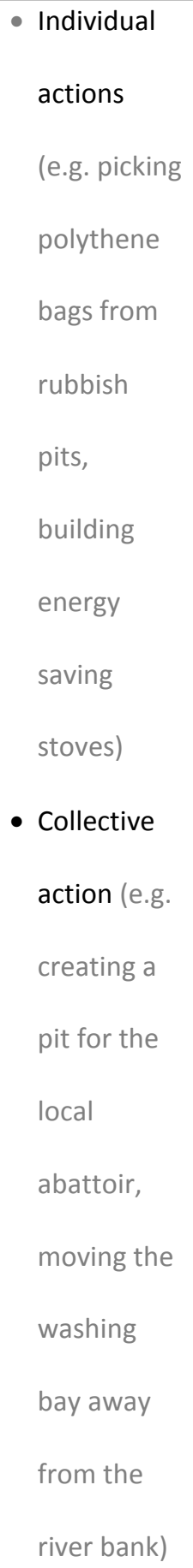 & - None \\
\hline $\begin{array}{l}\text { Social scales } \\
\text { of the }\end{array}$ & $\begin{array}{l}\text { Within and } \\
\text { beyond the }\end{array}$ & $\begin{array}{l}\text { Only within } \\
\text { the group(s) }\end{array}$ & $\begin{array}{l}\text { Within and } \\
\text { beyond the }\end{array}$ & $\begin{array}{l}\text { Only within } \\
\text { the groups }\end{array}$ & $\begin{array}{l}\text { Only within } \\
\text { the group }\end{array}$ \\
\hline
\end{tabular}


Author-produced version of the article published in Journal of Environmental Management, 2015, N¹57, p.84-95. The original publication is available at http://www.sciencedirect.com

Doi:10.1016/j.jenvman.2015.04.012

\begin{tabular}{|c|c|c|c|c|c|}
\hline impacts & $\begin{array}{l}\text { group(s) } \\
\text { involved in } \\
\text { the process }\end{array}$ & $\begin{array}{l}\text { involved in } \\
\text { the process }\end{array}$ & $\begin{array}{l}\text { group(s) } \\
\text { involved in } \\
\text { the process }\end{array}$ & $\begin{array}{l}\text { involved in } \\
\text { the process }\end{array}$ & $\begin{array}{l}\text { involved in } \\
\text { the process }\end{array}$ \\
\hline Spatial extent & $\begin{array}{l}\text { In and beyond } \\
\text { the area } \\
\text { where the } \\
\text { process was } \\
\text { implemented }\end{array}$ & $\begin{array}{l}\text { Only in the } \\
\text { area where } \\
\text { the process } \\
\text { was } \\
\text { implemented }\end{array}$ & $\begin{array}{l}\text { Only in the } \\
\text { area where } \\
\text { the process } \\
\text { was } \\
\text { implemented }\end{array}$ & $\begin{array}{l}\text { Only in the } \\
\text { area where } \\
\text { the process } \\
\text { was } \\
\text { implemented }\end{array}$ & $\begin{array}{l}\text { Only in the } \\
\text { area where } \\
\text { the process } \\
\text { was } \\
\text { implemented }\end{array}$ \\
\hline $\begin{array}{l}\text { Time scales of } \\
\text { impact }\end{array}$ & $\begin{array}{l}\text { Short- } \\
\text { medium term }\end{array}$ & $\begin{array}{l}\text { Short- } \\
\text { medium term }\end{array}$ & $\begin{array}{l}\text { Short- } \\
\text { medium term }\end{array}$ & $\begin{array}{l}\text { Short- } \\
\text { medium term }\end{array}$ & $\begin{array}{l}\text { Short- } \\
\text { medium term }\end{array}$ \\
\hline
\end{tabular}

For all five case studies, quite extensive M\&E activities were implemented. In the three Southeast Asian case studies, M\&E objectives were research, beneficiary and donororiented. In the two African case studies, M\&E objectives were research and beneficiaryoriented. In all five case studies, evaluators were members of the team organizing and facilitating the participatory process. In the three Southeast Asian case studies, they were supported by external independent consultants while in Uganda, M\&E was partly transferred to process participants. Two qualitative and one quantitative M\&E methods were used in all case studies: participant observation, interviews and surveys. Additional qualitative methods used in Uganda and Ethiopia included field notes, logbooks, literature review, questionnaires and expectations. An additional quantitative method used in these two cases was the counting of instances of occurrence in participatory events.

\section{Discussion}

We applied the COPP framework to five cases of participatory processes across five different contexts. The goal was to test first if the framework facilitated the development of a 
Author-produced version of the article published in Journal of Environmental Management, 2015, N¹57, p.84-95. The original publication is available at http://www.sciencedirect.com

Doi:10.1016/j.jenvman.2015.04.012

comprehensive and clear description of participatory processes, and second, if the descriptions facilitated a diagnostic step by applying a cross-comparative perspective. Ultimately, the purpose of this cross-comparison is to analyze the effectiveness of participatory processes and their elements. Clearly, these questions will not find a final answer in this paper as the COPP framework requires testing by the broader research and practitioner community. The effectiveness of the COPP framework depends on the willingness and capacity of other scholars to apply the framework and, thereby, subsequently improve its theoretical structure and practical implementation. It will also prove its effectiveness by leading to insights resulting from the comparative analysis of COPP-based descriptions. Finally, effectiveness of the COPP framework will also depend on how easily participatory processes can be replicated based on COPP-based descriptions.

\section{Is the COPP framework providing a clear and comprehensive description and is it sufficiently generic?}

The first element entails that descriptions of participatory processes are sufficiently clear and comprehensive so that readers get a complete and clear understanding of what the participatory project entailed and what outcomes it produced. This implies that the COPP framework can be applied consistently across multiple settings. The application of the COPP framework to the five case studies shown in Section 4 was not without challenges.

Not unexpectedly, it was a considerable challenge to describe the context of the participatory process in only five variables. From a field work perspective, such simplification neglects the contextual richness and thereby characteristics that potentially determined process outcomes. For a cross-comparative diagnostic however, contextual richness needs to be delimited to a level where the comparison of case studies is tractable. Reducing the context to key characteristics is therefore imperative to facilitate diagnosis. 
Author-produced version of the article published in Journal of Environmental Management, 2015, N¹57, p.84-95. The original publication is available at http://www.sciencedirect.com

Doi:10.1016/j.jenvman.2015.04.012

The application of the process related dimension and its fourteen variables was comparably easy for all five case studies. The description of outputs, outcomes and impacts, however, was challenging as the distinction between "impact on participants" and "impact on actions" and their social, spatial and temporal extent seemed rather subjective. This subjectivity can be reduced by having a proper M\&E system in place that actually reflects the outcome and impact variables adequately. The clarification of the three M\&E elements in the five case studies was easy and clear as it largely required the description of methods or steps.

Despite a few challenges, the five case studies suggested that the COPP framework is sufficiently generic to derive clear and consistent descriptions. The context-related limitations are likely to constrain diagnostic work as comparative studies might not be able to utilize information across all variables; some information might still be too context specific. In contrast, some of the contextual richness is lost as the result of the standardized description. An important aim of the paper is to catalyze efforts to discover the attributes of contextual information that are most effective in facilitating a comparative analysis, contributing to future COPP revisions and possibly a more generalizable COPP framework.

\section{What insights does the comparative perspective provide?}

From a diagnostic perspective, a sample of five case studies restricts the derivation of robust insights. Nevertheless, our goal was a pragmatic examination of the COPP framework, comparing available case studies to establish a foundation for expanded hypothesis testing. Impacts beyond the groups involved in the process are only reported for two of the five case studies while all five case studies report action level impacts. A multilevel approach is a common characteristic in four of the five examples, combining focus on improved participants' system understanding and decision-specific support. The potential derived 
Author-produced version of the article published in Journal of Environmental Management, 2015, N¹57, p.84-95. The original publication is available at http://www.sciencedirect.com

Doi:10.1016/j.jenvman.2015.04.012

hypothesis is that multilevel engagement is more likely to lead to outcomes. Current literature supports this hypothesis, and investigates which levels are needed and how to engage them (e.g. Daniell \& Barreteau, 2014).

Another example for formulating testable hypotheses from the diagnostic comparative approach is that there is a high potential for method substitution. Some of the case studies described above worked with visions and simulation modelling while others worked with role-playing games. This emphasizes the need to improve our understanding of the effectiveness of specific methods in specific situations. Applying the COPP framework to a much larger set of case studies would allow for testing the hypotheses that: a) specific methods are easily replaceable, for instance computational modelling with role-playing games; and b) the degree of system complexity will erode or compromise the effectiveness of specific methods.

A third hypothesis derived from the application of the COPP framework is linked to the implementation mode. All case studies document successful impacts on planning or decision-making processes. While all case studies have been implemented with multiple ongoing interactions, workshops and face-to-face meetings, the three Mekong cases, which showed broader social and spatial impacts, have been implemented over a period of more than two years. Also the implementation itself involved local on-the-ground coordination. The potential hypothesis derived from this comparison would test whether a minimum engagement period of two years, with regular events and local coordination, is more likely to lead to the achievement of project objectives. Literature based insights point to Daniell (2012) who describes a counter example indicating potential for revision and refutation of this hypothesis. Again, this would need to be tested with a much larger number of case studies. 
Author-produced version of the article published in Journal of Environmental Management, 2015, №157, p.84-95. The original publication is available at http://www.sciencedirect.com

Doi:10.1016/j.jenvman.2015.04.012

These three proposed hypotheses indicate the application of the COPP framework as a diagnostic, comparative device and a reference to develop hypotheses to test the efficacy of process characteristics and attributes. Ultimately, the purpose of this cross-comparison is to analyze the effectiveness of participatory processes and their elements. Given the complexity of the systems and players and the variability in contexts, processes and outcomes, there exists a risk that such a systematic comparison would fail in capturing some of the key elements that determine effectiveness. For instance, decision-makers' commitments to embrace participatory processes outputs or stakeholders' view of their own capacity to influence the process and its outcomes can play a critical role in process effectiveness. Yet these elements are very subjective and difficult to evaluate. But it is only after comparing a critical sample of cases that we will be able to refine the framework and to identify the potential recurrence of the derived hypothesis. Therefore, failure is a risk we are willing to take considering that conversely, success of our endeavour would substantially contribute to the advancement of this increasingly prominent research domain. In addition, a second major added-value of the framework is to point out critical elements a participatory processes should entail. As a result, even if identification of key effectiveness elements fails, comparison of a larger number of cases and refinement of the framework would still be a substantial contribution to research on participatory processes in that respect.

\section{Conclusion}

This paper developed a framework that aims for a clear and comprehensive description of participatory processes and their comparison. Ultimately, the purpose of this crosscomparison was to analyze the effectiveness of participatory processes and their elements. 
Author-produced version of the article published in Journal of Environmental Management, 2015, N¹57, p.84-95. The original publication is available at http://www.sciencedirect.com

Doi:10.1016/j.jenvman.2015.04.012

The framework was applied to an initial small sample of five case studies in Southeast Asia and East Africa. The small size of this sample precluded robust generalizable claims.

However, it allowed us to conclude that the COPP framework has the potential to be sufficiently generic and comprehensive to allow for further diagnostic steps. Three hypotheses were derived from this initial application which could be used as a basis for the development of further formal testable hypotheses in subsequent analytical steps. These are: 1 / multilevel engagement is more likely to lead to outcomes, $2 /$ specific methods are easily replaceable and the degree of system complexity will erode or compromise the effectiveness of specific methods and $3 /$ a minimum engagement period of two years, with regular events and local coordination, is more likely to lead to the achievement of project objectives. We recommend further testing of the COPP framework by the community of researchers and practitioners. We argue that such testing would not only promote exchanges of experiences and learning among the community, but would also provide a greater understanding of participatory processes, their context and their outcomes. In turn, this would guide researchers and practitioners in designing future participatory processes.

\section{Acknowledgements}

Discussions on the development of this paper started at the French Australian Water and Land Management Forum which took place in Canberra in June 2013. The authors would like to thank the organizers of the Forum for giving them the opportunity to meet and for initiating discussions on this paper. Special thanks are directed to Katherine Daniell for her comments. Work on the African participatory processes was supported by the AfroMaison European FP7 research project and the UNESCO Chair in Water Economics and Transboundary Water Governance. The donors did not have any direct role in study design, in the collection, analysis and interpretation of data, in the writing of the report; or in the 
Author-produced version of the article published in Journal of Environmental Management, 2015, №157, p.84-95. The original publication is available at http://www.sciencedirect.com

Doi:10.1016/j.jenvman.2015.04.012

decision to submit the article for publication. The views expressed are those of the authors

and do not reflect the official position of the donors. The authors thank the three

anonymous reviewers for their constructive comments and experience sharing. Finally, the authors thank all the collaborators to these five participatory processes, without whom this work could not have been done.

\section{References}

Abelson, J., Forest, P.-G., Eylesa, J., Smith, P., Martin, E., \& Gauvin, F.-P. (2003). Deliberations about deliberative methods: issues in the design and evaluation of public participation processes. Social Science \& Medicine, 57, 239-251.

Allison, H. E., \& Hobbs, R. J. (2006). Science and Policy in Natural Resource Management: Understanding System Complexity. Cambridge: Cambridge University Press.

Annese, S., \& Traetta, M. (2012). Distributed participation in blended learning communities: actors, contexts and groups. International Journal of Web Based Communities, 8(4), 422-439. doi:10.1504/IJWBC.2012.049558

Arnstein, S. R. (1969). A Ladder Of Citizen Participation. Journal of the American Institute of Planners, 35(4), 216-224. doi:10.1080/01944366908977225

Ashford, N. (1984). Advisory committees in OSHA and EPA: Their use in regulatory decisionmaking. Science, Technology, and Human Values, 9(1), 72-82.

Babby, E. R. (2004). The practice of social research. Belmont, CA: Thomson Wadsworth.

Barreteau, O., Bots, P. W., \& Daniell, K. A. (2010). A Framework for Clarifying "Participation" in Participatory Research to Prevent its Rejection for the Wrong Reasons. Ecology and Society, 15(2), 1. Retrieved from http://www.ecologyandsociety.org/vol15/iss2/art1/

Beierle, T. C., \& Cayford, J. (2002). Democracy in practice: public participation in environmental decisions (1st ed.). Washington D.C.: Resources for the Future.

Beierle, T. C., \& Konisky, D. M. (2000). Values, conflict, and trust in participatory environmental planning. Journal of Policy Analysis and Management, 19(4), 587-602. doi:10.1002/15206688(200023)19:4<587::AID-PAM4>3.0.CO;2-Q

Bellamy, J. A., Walker, D. H., McDonald, G. T., \& Syme, G. J. (2001). A systems approach to the evaluation of natural resource management initiatives. Journal of Environmental Management, 63(4), 407-423. doi:10.1006/jema.2001.0493

Berry, J. M., Portney, K. E., Bablich, M. B., \& Mahoney, R. (1984). Public involvement in administration: The structural determinants of effective citizen participation. Journal of Voluntary Action Research, 13(2), 7-23. doi:10.1177/089976408401300203 
Author-produced version of the article published in Journal of Environmental Management, 2015, N¹57, p.84-95. The original publication is available at http://www.sciencedirect.com

Doi:10.1016/j.jenvman.2015.04.012

Biggs, S. (1989). Resource-Poor Farmer Participation in Research: a Synthesis of Experiences From Nine National Agricultural Research Systems. OFCOR Comparative Study Paper (No. 3). The Hague.

Bots, P., \& van Daalen, C. (2008). Participatory model construction and model use in natural resource management: a framework for reflection. Systemic Practice and Action Research, 21(6), 381515. doi:10.1007/s11213-008-9108-6

Boyd, A., Geerling, T., Gregory, W. J., Kagan, C., Midgley, G., Murray, P., \& Walsh, M. P. (2007). Systemic Evaluation: A Participative, Multi-Method Approach. The Journal of the Operational Research Society, 58(10), 1306-1320. doi:10.1057/palgrave.jors.260228

Branch, K. M., \& Bradbury, J. A. (2006). Comparison of DOE and army advisory boards: Application of a conceptual framework for evaluating public participation in environmental risk decision making. Policy Studies Journal, 34(4), 723-754.

Brocklesby, J. (2009). Ethics beyond the model: How social dynamics can interfere with ethical practice in operational research/management science. Omega, 37(6), 1073-1082. doi:10.1016/j.omega.2008.12.004

Brown, T. C. (1984). The Concept of Value in Resource Allocation. Land Economics, 60(3), 231-246. doi:10.2307/3146184

Burton, P., Goodlad, R., \& Croft, J. (2006). How Would We Know What Works?: Context and Complexity in the Evaluation of Community Involvement. Evaluation.

Burton, P., Goodlad, R., Croft, J., Abbott, J., Hastings, A., Macdonald, G., \& Slater, T. (2004). What works in community involvement in area-based initiatives? A systematic review of the literature. Retrieved from http://webarchive.nationalarchives.gov.uk/20110218135832/http:/rds.homeoffice.gov.uk/rds/ pdfs04/rdsolr5304.pdf

Buysse, V., Wesley, P., \& Skinner, D. (1999). Community development approaches for early intervention. Topics in Early Childhood Special Education, 19, 236-243.

Byrne, D. (2013). Evaluating complex social interventions in a complex world. Evaluation, 19(3), 217228. doi:10.1177/1356389013495617

Carr, D. S., \& Halvorsen, K. (2001). An evaluation of three democratic, community-based approaches to citizen participation: Surveys, conversations with community groups, and community dinners. Society and Natural Resources, 14(2), 107-126.

Carron, A. V., \& Spink, K. S. (1995). The Group Size-Cohesion Relationship in Minimal Groups. Small Group Research, 26(1), 86-105. doi:10.1177/1046496495261005

Chambers, R. (2002). Participatory Workshops: 21 Sources of Ideas and Activities. London and Sterling, VA.: Earthscan.

Champion, D., \& Wilson, J. M. (2010). The impact of contingency factors on validation of problem structuring methods. Journal of the Operational Research Society, 61, 1420-1431. doi:10.1057/jors.2009.94

Checkland, P., \& Scholes, J. (1990). Soft systems methodology in action. Chichester et al. Chichester: Wiley. 
Author-produced version of the article published in Journal of Environmental Management, 2015, N¹57, p.84-95. The original publication is available at http://www.sciencedirect.com

Doi:10.1016/j.jenvman.2015.04.012

Chess, C. (2000). Evaluating Environmental Public Participation: Methodological Questions. Journal of Environmental Planning and Management, 43(6), 769-784. doi:10.1080/09640560020001674

Chess, C., \& Purcell, K. (1999). Public Participation and the Environment: Do We Know What Works? Environmental Science \& Technology, 33(16), 2685-2692. doi:10.1021/es980500g

Cleaver, F., \& Franks, T. (2005). How Institutions Elude Design: River Basin Management and Sustainable Livelihoods. BCID Research Paper. Bradford Centre for International Development.

Conley, A., \& Moote, M. A. (2003). Evaluating Collaborative Natural Resource Management. Society \& Natural Resources, 16(5), 371-386. doi:10.1080/08941920309181

Connick, S., \& Innes, J. E. (2003). Outcomes of Collaborative Water Policy Making: Applying Complexity Thinking to Evaluation. IURD Working Paper Series, Institute of Urban and Regional Development, UC Berkeley, 46(2), 177-197. Retrieved from http://escholarship.org/uc/item/03f3b4z9

Couix, N. (1997). Chapitre 6 Evaluation « chemin faisant » et mise en acte d'une stratégie tâtonnante. In Economica (Ed.), La stratégie chemin-faisant.

Creswell, J. W. (1994). Research design: Qualitative and quantitative approaches. Thousand Oaks, CA: SAGE.

Crosby, N., Kelly, J. M., \& Schaefer, P. (1986). Citizens Panels: A New Approach to Citizen Participation. Public Administration Review, 46(2), 170-178. doi:10.2307/976169

Crotty, M. (1998). The foundations of social research: Meaning and perspective in the research process. London: SAGE.

Cumming, D. H. M. (2000). Drivers of resource management practices - fire in the belly? Comments on "Cross-cultural conflicts in fire management in northern Australia: not so black and white" by Alan Andersen. Conservation Ecology, 4(1), 4. Retrieved from http://www.consecol.org/vol4/iss1/art4/

Daniell, K. A. (2012). Co-Engineering and Participatory Water Management: Organisational Challenges for Water Governance. Cambridge: Cambridge University Press.

Daniell, K. A., \& Barreteau, O. (2014). Water governance across competing scales: Coupling land and water management. Journal of Hydrology. doi:10.1016/j.jhydrol.2014.10.055

Davidson, S. (1998). Spinning the wheel of empowerment. Planning, 1262(3), 14-15.

Davies, A. (1997). Managing for a Change: How to Run Community Development Projects. Colchester: Intermediate Technology Publications.

DFID. (2002). Tools for Development: A handbook for those engaged in development activity. London. Retrieved from http://www.dfid.gov.uk/pubs/files/toolsfordevelop

Dovers, S. (2003). Processes and institutions for resource and environmental management: why and how to analyze? In S. Dovers \& S. W. River (Eds.), Managing Australia's Environment (pp. 3-12). The Federation Press.

Dovers, S., \& Hussey, K. (2013). Environment \& Sustainability (2nd ed.). Sydney: The Federation Press. 
Author-produced version of the article published in Journal of Environmental Management, 2015, N¹57, p.84-95. The original publication is available at http://www.sciencedirect.com

Doi:10.1016/j.jenvman.2015.04.012

Einsiedel, E. ., Jelsøe, E., \& Breck, T. (2001). Publics at the technology table: The consensus conference in Denmark, Canada, and Australia. Public Understanding of Science, 10(1), 83 -98. doi:10.1088/0963-6625/10/1/306

Farrington, J. (1998). Organisational roles in farmer participatory research and extension: lessons from the last decade. Natural Resource Perspectives, 27, 1-4.

Ferrand, N., \& Daniell, K. A. (2006). Comment évaluer la contribution de la modélisation participative au développement durable ? In Séminaire DDT. Lille.

Fiorino, D. J. (1990). Citizen participation and environmental risk: A survey of institutional mechanisms. Science, Technology, \& Human Values, 15(2), 226-43.

Fishman, D. B. (1992). Postmodernism comes to program evaluation. Evaluation and Program Planning, 15(3), 263-270. doi:10.1016/0149-7189(92)90090-H

Foley, B. A., Daniell, T. M., \& Warner, R. F. (2003). What is Sustainability and can it be measured? Australian Journal of Multidisciplinary Engineering, 1(1), 1-8.

Folke, C., Hahn, T., Olsson, P., \& Norberg, J. (2005). Adaptive governance of Social-Ecological Systems. Annual Review of Environment and Resources, 30(1), 441-473. doi:10.1146/annurev.energy.30.050504.144511

Frewer, L. J., \& Rowe, G. (2005). Evaluating Public Participation Exercises: Strategic and Practical Issues. In Evaluating Public Participation in Policy Making (pp. 85-1008). Paris: OECD.

Fung, A. (2003). Recipes for Public Spheres: Eight Institutional Design Choices and Their Consequences. Journal of Political Philosophy, 11(1), 338-367.

Fung, A. (2006). Varieties of Participation in Complex Governance. Public Administration Review, 6675.

Galpin, M., Dorward, P., \& Shepherd, D. (2000). Participatory farm management methods for agricultural research and extension needs assessment: a manual.

GIS. (2011). Call for papers and papers' abstracts. In Study day on the effetcs of participation. Paris. Retrieved from http://www.participation-et-democratie.fr/en/content/papers-study-daysummaries1

Glicken, J. (2000). Getting stakeholder participation "right": a discussion of participatory processes and possible pitfalls. Environmental Science \& Policy, 3(6), 305-310.

Godschalk, D. R., \& Stiftel., B. (1981). Malking waves: Public participation in state water planning. Journal of Applied Behavioral Science, 17(4), 597-614. doi:10.1177/002188638101700413

Goetz, A., \& Gaventa, J. (2001). Bringing citizen voice and client focus into service delivery. Brighton: Institute of Development Studies.

Gurtner-Zimmermann, A. (1996). Analysis of Lower Green Bay and Fox River, Collingwood Harbour, Spanish Harbour, and the Metro Toronto and Region Remedial Action Plan (RAP) process. Environmental Management, 20(4), 449-459. 
Author-produced version of the article published in Journal of Environmental Management, 2015, N¹57, p.84-95. The original publication is available at http://www.sciencedirect.com

Doi:10.1016/j.jenvman.2015.04.012

Guston, D. H. (1999). Evaluating the First U.S. Consensus Conference: The Impact of the Citizens' Panel on Telecommunications and the Future of Democracy. Science, Technology \& Human Values, 24(4), 451-482. doi:10.1177/016224399902400402

Herrfahrdt-Pähle, E., \& Pahl-Wostl, C. (2012). Continuity and change in social-ecological systems: the role of institutional resilience. Ecology And Society, 17(2): 8. Retrieved from http://dx.doi.org/10.5751/ES-04565-170208

Houghton, D. G. (1988). Citizen advisory boards: Autonomy and effectiveness. American Review of Public Administration, 18(3), 283-296. doi:10.1177/027507408801800304

IAPP. (2004). Public Participation Toolbox. Retrieved from http://www.iap2.org/associations/

Indik, B. P. (1965). Operational size and member participation: Some empirical tests of alternative explanations. Human Relations, 18, 339-350.

Innes, J. E., \& Booher, D. E. (1999). Consensus Building and Complex Adaptive Systems: A Framework for Evaluating Collaborative Planning. Journal of the American Planning Association, 65(4), 412. Retrieved from http://proxy.library.oregonstate.edu/login?url=http://search.ebscohost.com/login.aspx?direct= true \&db=aph\&AN=2602188\&site=ehost-live

Involve. (2005). People and Participation: How to put citizens at the heart of decision-making. London. Retrieved from www.involve.org.uk/mt/archives/blog_13/People and\%

Jackson, M. C., \& Keys, P. (1984). Towards a System of Systems Methodologies. Journal of the Operational Research Society, 35(6), 473-486.

Jayakaran, R. (2003). Participatory Poverty Alleviation and Development: A Comprehensive Manual for Development Professionals. World Vision, China.

Kelly, K., \& Van Vlaenderen, H. (1995). Evaluating participation processes in community development. Evaluation and Program Planning, 18(4), 371-383. doi:10.1016/0149-7189(95)00030-5

Krywkow, J. (2009). Methodological Framework for Participatory Processes in Water Resources Management. University of Twente.

Landre, B. K., \& Knuth, B. A. (1993). The role of agency goals and local context in Great Lakes water resources public involvement programs. Environmental Management, 17(2), 153-165.

Lankford, B. A. (2008). Integrated, adaptive and domanial water resources management. In C. PahlWostl, P. Kabat, \& J. Möltgen (Eds.), Adaptive and Integrated Water Management: Coping with Complexity and Uncertainty (pp. 39-59). Berlin Heidelberg: Springer.

Laughlin, R., \& Broadbent, J. (1996). Redesigning Fourth generation Evaluation: An Evaluation Model for the Public-sector Reforms in the UK? Evaluation, 2(4), 431-451. doi:10.1177/135638909600200406

Lawrence, A. (2006). “No Personal Motive?” Volunteers, Biodiversity, and the False Dichotomies of Participation. Ethics, Place \& Environment, 9(3), 279-298. doi:10.1080/13668790600893319

Lincoln, Y. S., \& Guba, E. G. (1989). Fourth Generation Evaluation. Thousand Oaks, CA: Sage. 
Author-produced version of the article published in Journal of Environmental Management, 2015, №157, p.84-95. The original publication is available at http://www.sciencedirect.com

Doi:10.1016/j.jenvman.2015.04.012

Lynam, T., De Jong, W., Sheil, D., Kusumanto, T., \& Evans, K. (2007). A Review of Tools for Incorporating Community Knowledge, Preferences, and Values into Decision Making in Natural Resources Management. Ecology And Society, 12(1), 5. doi:5

MacNair, R. H., Caldwell, R., \& Pollane, L. (1983). Citizen participants in public bureaucracies: Foulweather friends. Administration \& Society, 14(4), 507-523.

Mayoux, L. (2005). Quantitative Qualitative or Participatory? Which Method, for What and When? In V. Desai \& R. B. Potter (Eds.), Doing Development Research (pp. 115-129). Thousand Oaks, London, New Delhi: Sage.

McAllister, K. (1999). Understanding Participation: Monitoring and evaluating process, outputs and outcomes. Ottawa: International Development Research Centre. Retrieved from https://idlbnc.idrc.ca/dspace/bitstream/10625/24628/1/114210.pdf

McGurk, B., Sinclair, A. J., \& Diduck, A. (2006). An Assessment of Stakeholder Advisory Committees in Forest Management: Case Studies from Manitoba, Canada. Society \& Natural Resources, 19(9), 809-826. doi:10.1080/08941920600835569

Michener, V. J. (1998). The participatory approach: Contradiction and co-option in Burkina Faso. World Development, 26(12), 2105-2118. doi:10.1016/S0305-750X(98)00112-0

Midgley, G. (1997). Dealing with coercion: Critical Systems Heuristics and beyond. Systems Practice, 10(1), 37-57.

Midgley, G. (2007). Systems thinking for evaluation. In B. Williams \& I. Imam (Eds.), Systems concepts in evaluation: An expert anthology (pp. 11-34). American Evaluation Association.

Midgley, G., Cavana, R. Y., Brocklesby, J., Foote, J. L., Wood, D. R. R., \& Ahuriri-Driscoll, A. (2013). Towards a new framework for evaluating systemic problem structuring methods. European Journal of Operational Research, 229(1), 143-154. doi:10.1016/j.ejor.2013.01.047

Mikkelsen, B. (2005). Methods for Development Work and Research: A New Guide for Practitioners (2nd ed.). New Delhi, Thousand Oaks, London: Sage.

More, T. A., Averill, J. R., \& Stevens, T. H. (1996). Values and economics in environmental management: A perspective and critique. Journal of Environmental Management, 48(4), 397409. doi:10.1006/jema.1996.0086

Morgan, L. M. (2001). Community participation in health: perpetual allure, persistent challenge. Health Policy and Planning, 16(3), 221-230. doi:10.1093/heapol/16.3.221

Mullen, B., Johnson, D. A., \& Drake, S. D. (1987). Organizational Productivity as a Function of Group Composition: A Self-Attention Perspective. Journal of Social Psychology, 127(2), 143-150. doi:10.1080/00224545.1987.9713673

Murphy-Berman, V., Schnoes, C., \& Chambers, J. M. (2000). An early stage evaluation model for assessing the effectiveness of comprehensive community initiatives: Three case studies in Nebraska. Evaluation and Program Planning, 23(2), 157-163. doi:10.1016/S01497189(00)00010-0

New Economics Foundation. (1998). Participation Works! 21 techniques of community participation for the 21st century. London. 
Author-produced version of the article published in Journal of Environmental Management, 2015, N¹57, p.84-95. The original publication is available at http://www.sciencedirect.com

Doi:10.1016/j.jenvman.2015.04.012

Nunamaker, J. F., Dennis, A. R., Valacich, J. S., Vogel, D. R., \& George, J. F. (1991). Electronic meeting systems to support group work. In Communications of the ACM 34 (pp. 43-61).

OECD. (2001). Citizens as Partners: Information, Consultation and Public Participation in PolicyMaking. Paris: OECD Publishing.

Okali, C., Sumberg, J., \& Farrington, J. (1994). Farmer Participatory Research. London: Intermediate Technology Publications.

Ong, B. N. (2000). Assessing the context for partnerships between communities and the National Health Service in England. Critical Public Health, 10(3), 343-351. doi:10.1080/713658254

Ostrom, E. (2005). Understanding Institutional Diversity. Princeton: Princeton University Press.

Ostrom, E. (2009). A general framework for analyzing sustainability of social-ecological systems. Science, 325(5939), 419-22. doi:10.1126/science.1172133

Patton, M. Q. (1999). Enhancing the quality and credibility of qualitative analysis. Health Services Research, 34(5 Part II), 1189-1208.

Peelle, E., Schweitzer, M., Munro, J., Carnes, S., \& Wolfe, A. (1996). Factors favorable to public participation success. In National Association of Environmental Professionals, Houston, TX, June 2-5. Oak Ridge, TN: Oak Ridge National Laboratory.

Perez, P., Aubert, S., Daré, W., Ducrot, R., Jones, N., Queste, J., ... Van Paassen, A.-M. (2011). Assessment and monitoring of the effects of the ComMod approach. In M. Etienne (Ed.), Companion modelling A participatory approach to support sustainable development (Quae., pp. 141-167). Versailles.

Petts, J. (1995). Waste Management Strategy Development: A Case Study of Community Involvement and Consensus-Building in Hampshire. Journal of Environmental Planning and Management, 38(4), 519-536. doi:10.1080/09640569512797

Petts, J. (2001). Evaluating the Effectiveness of Deliberative Processes: Waste Management Casestudies. Journal of Environmental Planning and Management, 44(2), 207-226. doi:10.1080/09640560120033713

Poteete, A. R., Janssen, M. A., \& Ostrom, E. (2010). Working togeher: collective action, the commons, and multiple methods in practice. Princeton: Princeton University Press.

Pretty, J. N. (1995). Participatory learning for sustainable agriculture. World Development. doi:10.1016/0305-750X(95)00046-F

Pretty, J. N., Gujit, I., Scoones, I., \& Thompson, J. (1995). A trainers guide for participatory learning and action. In IIED Trainer's Guide (pp. 59-96). IIED.

Renger, R., Wood, S., Williamson, S., \& Krapp, S. (2011). Systemic evaluation, impact evaluation and logic models. Evaluation Journal of Australasia, 11(2), 24-30.

Renn, O., Webler, T., \& Wiedemann, P. (1995). Fairness and competence in citizen participation: Evaluating models for environmental discourse. Dordrecht: Kluwer Academic.

Rennie, J. K., \& Singh, N. C. (1996). Participatory research for sustainable livelihoods: a guidebook for field projects. Ottawa: International Institute for Sustainable Development. 
Author-produced version of the article published in Journal of Environmental Management, 2015, N¹57, p.84-95. The original publication is available at http://www.sciencedirect.com

Doi:10.1016/j.jenvman.2015.04.012

Richards, C., Blackstock, K. L., \& Carter, C. E. (2004). Practical Approaches to Participation (No. 1). Aberdeen.

Rietbergen-McCracken, J., \& Narayan, D. (1996). The World Bank Participation Sourcebook: Appendix 1 Methods and Tools: SARAR. Washington D.C.

Rosener, J. B. (1981). User-Oriented Evaluation: A New Way to View Citizen Participation. Journal of Applied Behavioral Science, 17(4), 583-596. doi:0.1177/002188638101700412

Rossi, P. H., Freeman, H. E., \& Lipsey, M. (1999). Evaluation: a systematic approach. Thousand Oaks, CA: Sage.

Rowe, G., \& Frewer, L. J. (2000). Public Participation Methods: A Framework for Evaluation. Science, Technology \& Human Values, 25(1), 3-29.

Rowe, G., \& Frewer, L. J. (2004). Evaluating Public-Participation Exercises: A Research Agenda. Science Technology And Human Values, 29(4), 512-556. Retrieved from http://sth.sagepub.com/cgi/doi/10.1177/0162243903259197

Rowe, G., Marsh, R., \& Frewer, L. J. (2004). Evaluation of a Deliberative Conference. Science, Technology, \& Human Values, 29(1), 88-121. doi:10.1177/0162243903259194

Sabatier, P. A. (1988). An advocacy coalition framework of policy change and the role of policyoriented learning therein. Policy Sciences, 21(2-3), 129-168.

Saleth, R. M. (2006). Understanding water institutions: Structure, Environment and Change Process. In Water Governance for Sustainable Development: Approaches and Lessons from Developing and Transitional countries (pp. 3-20). Paris: Routledge.

Scott, W. R. (2001). Institutions and organizations (2nd ed.). Thousand Oaks, CA: Sage.

Scottish Parliament. (2004). Participation Handbook. Edinburgh. Retrieved from www.scottish.parliament.uk/

Sewell, W., \& Phillips, S. (1979). Models for the evaluation of public participation programs. Natural Resources Journal, 19, 337-358.

Shah, M. K., Kambou, S. D., \& Monahan, B. (1999). Embracing Participation in Development: Worldwide Experience from CARE's Reproductive Health Programs. USA.

Slater, P. E. (1958). Contrasting correlates of group size. Sociometry, 21, 129-139. doi:10.2307/2785897

Smajgl, A., \& Ward, J. (2013). A framework to bridge science and policy in complex decision making arenas. Futures, 52, 52-58. doi:10.1016/j.futures.2013.07.002

Syme, G. J., \& Sadler, B. S. (1994). Evaluation of Public Involvement in Water Resources Planning: A Researcher-Practitioner Dialogue. Evaluation Review, 18(5), 523-542. doi:10.1177/0193841X9401800501

Thomas, E. J., \& Fink, C. F. (1963). Effects of group size. Psychological Bulletin, 60(4), 371-384. doi:10.1037/h0047169 
Author-produced version of the article published in Journal of Environmental Management, 2015, N¹57, p.84-95. The original publication is available at http://www.sciencedirect.com

Doi:10.1016/j.jenvman.2015.04.012

Tippett, J., Handley, J. F., \& Ravetz, J. (2007). Meeting the challenges of sustainable development - A conceptual appraisal of a new methodology for participatory ecological planning. Progress in Planning, 67(1), 9-98. doi:10.1016/j.progress.2006.12.004

Ulrich, W. (1983). Critical Heuristics of Social Planning: A New Approach to Practical Philosophy. Bern: Haupt.

Warburton, D., Wilson, R., \& Rainbow, E. (2007). Making a Difference : A guide to evaluating public participation in central government. Research Practice, (25 July), 1-13. Retrieved from http://www.involve.org.uk/wp-content/uploads/2011/03/Making-a-Difference-.pdf

Warner, M. (1997). “Consensus" participation: an example for protected areas planning. Public Administration and Development, 17, 413-432. doi:10.1002/(SICI)1099162X(199710)17:4<413::AID-PAD952>3.0.CO;2-P

Wates, N. (2000). The Community Planning Handbook: How People can Shape their Cities Towns and Villages. London: Earthscan.

Webler, T., \& Tuler, S. (2002). Unlocking the Puzzle of Public Participation. Bulletin of Science, Technology \& Society, 22(3), 179-189. doi:10.1177/02767602022003002

White, L. (2006). Evaluating problem-structuring methods: developing an approach to show the value and effectiveness of PSMs. Journal of the Operational Research Society, 57(7), 842-855. doi:10.1057/palgrave.jors.2602149

William, B. (2007). Systems concept in evaluation An Expert Anthology. (B. William \& I. Imam, Eds.) (p. 222). Point Reyes, CA: EdgePress.

Young, O. R. (2008). Institutions and Environmental Change: The Scientific Legacy of a Decade of IDGEC Research. In Institutions and Environmental Change, Principal Findings, Applications, and Research Frontiers (pp. 3-45). Cambridge, London: MIT Press. 
Author-produced version of the article published in Journal of Environmental Management, 2015, Nㅜ157, p.84-95. The original publication is available at http://www.sciencedirect.com

Doi:10.1016/j.jenvman.2015.04.012

\section{ANNEX 1: Framework application template}

\section{A. Context-related characteristics}

A1 What are the system elements the participatory process targets to improve?

(Multiple options can be chosen $\square$ )

Natural / Environmental: e.g. water, forests, wetlands

$\square$ Economic: e.g. labor, import-export

Social: e.g. livelihoods, migration

Political: e.g. votes, policies

Urban: e.g. infrastructures, housing

Health: e.g. facilities, equipment

Technological: e.g. internet

Educational: e.g. curriculum, classes

A2 Which levels of governance are critical influencers of the target system elements?

(Multiple options can be chosen

च)

Macro (national or larger)

Meso (subnational)

Micro (village or group of villages)

A3 Have there been previous intervention attempts aiming to influence the selected target system elements?

$\square$ Many

Few

None

A4 What relationships existed between participants before the participatory process started?

$\square \quad$ No pre-existing relationship

$\square \quad$ High degree of mistrust / conflict

$\square$ Moderate trust and conflict

$\square$ Good pre-existing relationships and trust

A5 How well did participants understand the target system elements before the participatory process started?

$\square \quad$ The majority of participants state they understand target system elements

$\square \quad$ The majority of participants state they do not understand target system elements 


\section{B. Process-related characteristics}

B1 What are the main objectives of the participatory process?

(Multiple options can be chosen $\square$ )

Exploring decision-making options (e.g. planning, laws)

Improve participants' system understanding

Resolving or avoiding conflicts

Gathering knowledge (e.g. mapping of the social-environmental system, geographic information systems, inventory)

B2 Who had the initial idea and instigated the process first?

(Multiple options can be chosen $\square$ )

Donor or development agency (e.g. call for projects)

$\square$ Researchers

$\square$ Decision-makers / government

$\square$ Civil society

Private sector

B3 Who lead the participatory process, organized and facilitated the events?

(Multiple options can be chosen $\square$ )

$\square$ Donor or development agency

Researchers

Decision-makers / government

Civil society

Private sector

\section{B4 What is the origin of the team?}

The majority of team members come from the area and/or are affected by the target system elements

$\square$ The majority of team members do not come from the area and are not affected by the target system elements

\section{B5 Who selected participants?}

(Multiple options can be chosen $\square$ )

Selected by the team

Selected by a third party, external of the organizing and facilitating team

B6 How many participants did the process actively involve (excl. team members)?

(In case of multiple parallel processes specify for each process separately.)

Over 50

Between 25 and 49

Between 12 and 24

Below 12 
Author-produced version of the article published in Journal of Environmental Management, 2015, №157, p.84-95.

The original publication is available at http://www.sciencedirect.com

Doi:10.1016/j.jenvman.2015.04.012

B7 What could participants' expectations best be described?

High: they believe this process can change the target system,

Low: they don't believe this process can change the target system

B8 How many levels of governance participated?

Single-level

Multiple-levels

B9 How long did the participatory process last? (Specify)

More than 5 years

1 to 5 years

Less than a year

B10 How many events took place in this timeframe?

Multiple events (specify)

Single event

B11 What is the approximate retention rate of participants during the process?

More than $75 \%$ of participants attended the whole process

50 to $74 \%$ of participants attended the whole process

25 to $49 \%$ of participants attended the whole process

Less than $24 \%$ of participants attended the whole process

B12 What is the main situation of participatory activities, the setting of exchange?

(Multiple options can be chosen $\square$ )

Participants are involved individually

Participants are involved as a group that is considered as a whole by the organizing and facilitating team, independent of participants' diversity

Participants are involved as a heterogeneous group

B13 What stages of the process were genuinely participatory?

$\square$ (Co-) design of the project proposal

$\square$ (Co-) design of the participatory process

(Co-) selection of process methods

$\square$ (Co-) selection of participants

$\square$ (Co-) facilitation of participatory events

(Co-) M\&E design

(Co-) selection of M\&E methods

(Co-) analysis of results

(Co-) communication of results

B14 What methods and tools did the participatory process employ?

(Multiple options can be chosen $\square$ )

Non-computerized model(s) (e.g. role-playing games, system representation(s))

Computerized model(s) 


\section{Outputs, outcomes and impacts-related characteristics}

\section{C1 What were the main outputs of the participatory process?}

(Multiple options can be chosen $\square$ )

New, revised or dismissed development plan / policy / investment / technology / law

Agreement, memorandum of understanding, terms of reference

Model

Investment in new infrastructure / land use change / management processes

$\square$ No specific artefact

C2 How can the main impact on participants best be described?

(Multiple options can be chosen $\square$ )

$\square \quad$ Reduction of conflict

Improved understanding of target system elements

Capacity building

Influence on decision

Increased collaboration, trust, networking, relationship building

None

C3 What was the main impact on actions implemented by participants?

(Multiple options can be chosen $\square$ )

$\square$ Individual behavioral change, change in daily practices and actions

Collective actions

$\square$ None

C4 At which social scales did the impacts realise?

Only within the group(s) involved in the process

Within and beyond the group(s) involved in the process

\section{C5 What was the spatial extent of impacts achieved?}

Only in the area where the process was implemented

In and beyond the area where the process was implemented

\section{C6 What are the time scales of impacts?}

(Multiple options can be chosen $\square$ )

$\square \quad$ Short term

Medium term

Long term 